\title{
Mitigating energy poverty: potential contributions of combining PV and building thermal mass storage in low-income households
}

\author{
Laura Romero Rodríguez, José Sánchez Ramos, María del Carmen Guerrero Delgado, José Luis \\ Molina Félix, Servando Álvarez Domínguez \\ Grupo de Termotecnia. Escuela Técnica Superior de Ingenieros. University of Seville, Spain.
}

\begin{abstract}
The issue of energy poverty has devastating implications for the society, and it has been aggravated in the past years due to the economic crisis and the increase of energy prices. Among the most affected are those with low incomes and living in inefficient buildings. Unfortunately, the bitter reality is that sometimes this part of the population are facing the next question: Heating, or eating? The declining prices of distributed energy technologies such as photovoltaics provides an opportunity for positive social change. Although their use does not address energy poverty directly, substantial contributions may be made.

Measurements of indoor temperatures in a social housing district of southern Spain in 2017 have revealed the unbearable temperatures that the occupants have to endure, both in summer and winter. Using this district as a case study, the present work aims to evaluate the benefits of exploiting its rooftop PV potential to cover part of the electricity consumption of the district (reducing the energy bills), and use the surplus electricity to supply power for the heat pumps in the district. Optimal alternatives regarding maximum PV production, maximum self-sufficiency ratio and minimum investment costs have been found, considering as well different options when sharing the available electricity surplus to improve the thermal comfort of the occupants. As far as the authors know, no previous study has followed an approach aimed at energy poverty alleviation such as the one presented in this work. The results show that using the surplus electricity to heat or cool the whole dwellings would improve the thermal comfort of the occupants in average up to $11 \%$ in winter and $26 \%$ in summer. If all the PV generation was used or more buildings in the area were employed to install PV modules, improvements up to $33 \%$ in winter and $67 \%$ in summer could be obtained, reducing at the same time the thermal comfort differences among the dwellings of the district.
\end{abstract}

Keywords: energy poverty; fuel poverty; PV potential; thermal comfort.

\section{Introduction}

\subsection{Background}

Cities have become one of the cornerstones in fighting climate change due to their increasing electricity demand. Although in the past this was mostly covered by using fossil fuels in large centralized power plants, the use of renewable energies is becoming widespread due to their proven contribution to mitigate global warming and the fact that they provide local, clean and abundant sources of energy. The transition to smart microgrids which make use of distributed renewable energy generation systems such as photovoltaic (PV) or wind energy is also being promoted, and there is a huge potential to utilize them not only to satisfy demand and provide decentralized generation, but also to help tackling fuel poverty and achieving emission 

frequently considered to be the best candidate on a large scale.

Despite the enormous benefits of renewable energy systems (RES), there is a drawback that should be considered: an extensive use inserts uncertainty into the grid due to their dependency on weather conditions. A large amount of intermittent renewable energy in the energy system is a major challenge, since supply and demand must match at any time [2]. For this reason there is a need for power reserve, and energy storage systems play a central role since they provide the means to balance energy generation and demand. Buildings can be part of the solution in future smart grids, offering different storage potentials in the structure itself (thermal storage) or in individual units such as water tanks or batteries [3], which also allow load shifting strategies.

The high energy consumption of the building sector, climate change and energy poverty are the major problems encountered in the built environment in Europe [4]. The three sectors are strongly interrelated, presenting significant synergies. When using buildings to service power flexibility requirements, case study based specifics should be considered [5]. According to [6], demand response in HVAC systems focuses on individual buildings, but their building-group performance, which is the real concern to the grid, has not been systematically evaluated. The number of studies on load matching has increased rapidly in the past years and most of them use approaches such as energy storage (batteries or thermal storage) and demand side management. However, the literature also shows that research is mostly focused on individual buildings when it comes to load matching [7]. Retrofit programs reduce carbon emissions to some degree, but the bigger challenge is addressing habitual household energy consumption [8]. In addition, retrofitting measures in social houses are usually undertaken by the housing company, so they require to be communicated, assimilated and accepted by the tenants [9].

\subsection{Energy poverty}

In spite of the rising electricity consumption in cities, there is a part of the population that is particularly vulnerable. Energy poverty refers to the situation in which a household is unable to maintain a proper level of indoor thermal comfort as a consequence of a combination of three causes: low income, high energy prices or poor energy efficiency of housing [10]. This affects the capacity of the occupants to consume energy so as to keep the proper indoor environmental conditions, thus deteriorating their health and quality of life. For these reasons, energy poverty is a serious problem in the European Union and the whole world. In parallel, the term fuel poverty is traditionally used to imply the inability to cover the heating or cooling needs. In addition, the role of the occupants for achieving energy savings is increasingly recognized and even more important in the social housing sector [11].

The problem of energy poverty has been aggravated in the past years, particularly in Spain, due to the economic crisis and the increase of energy prices. As a result, part of the population cannot cover their energy needs, reaching very low or very high indoor temperatures that may have a severe impact on their health and result in an increase of illnesses or even mortality. According to the study in [12], 5.1 million people in Spain, which means $11 \%$ of the households, claim that they are incapable of maintaining a proper indoor temperature in winter. Another of the used indicators shows that $7 \%$ of the Spanish households live in a situation of energy poverty. Andalusia, where the present study takes place, is the region in Europe with the highest solar energy potential [13]. However, heating is necessary in most European countries, even those in the south of the continent such as Spain. 
In particular, social housing and low-income households are the most vulnerable, since they present social and financial constraints and need to be one of the main targets when actions towards mitigating energy poverty are carried out. For example, a field investigation in [10] showed that the energy consumption in social dwellings was lower than expected not due to a good performance of the dwellings, but to a lowering of the indoor comfort levels. The study in [14] also shows that low income households showed minimum heating consumptions much below the normal thresholds. The work presented in [15] revealed that electricity demand responds positively to income, and negatively to electricity and gas prices. The study in [16] presents the state of the art regarding the energy demand and indoor environmental quality of low income households in Europe. Last of all, [17] evaluates the effect of customized consumption feedback in low-income households, confirming the importance of information and efficiency indicators.

\subsection{District PV potential and load matching}

Although the use of solar PV does not address fuel poverty directly, it can provide a great contribution towards diminishing the electricity demand in a social housing context. For instance, [18] showed that deploying solar panels in low-income housing units would contribute to energetic autonomy, reduce grid dependency and help to change the cultural perception towards renewable energy alternatives. In addition, [1] explores PV generation and how it can be used to provide added value in terms of demand reduction and contribute to a reduction in fuel poverty.

Until recently, there was no significant concern for grid operators due to low PV adoption rates. However, this is changing due to the increase of energy generation from PV systems, which is not usually aligned with the electricity demand. There are also concerns regarding the prevalence of PV in electricity networks. Concurrent with increasing electricity prices, the rewards for exported solar electricity are falling, thus local PV self-consumption is gaining attention [19]. [20] developed a methodology for predicting the impact of net metering restrictions on the deployment of residential solar systems. In this context, self-consumption with storage allows to highlight the prosumer concept (consumers that are also capable of producing their own energy), since this strategy may be interesting from a technical and economical perspective [21]. However, there may be conflicting interests between the users and the grid, since higher returns to PV owners lead to higher net load variance burdening the grid while smoothing the load profile leads to diminishing returns for the PV owners [22].

Household or community energy storage are two promising storage scenarios for residential electricity prosumers [23]. An interdisciplinary review of community energy storage is presented in [24]. Also, a new framework to integrate community storage units in an existing residential community system with rooftop PV is proposed in [25], and [19] compares the results of storage adoption at the level of individual households to storage adoption on the community level using the aggregated community demands, highlighting the need for energy policy to develop market mechanisms that facilitate the deployment of community storage. This study also illustrates that community storage decreases the total amount of storage deployed, decreasing surplus PV generation and therefore increasing self-sufficiency. Even though battery storage systems implemented with PV have been widely documented in literature since the costs have been decreasing and their reliability has improved, most authors agree that it is still an unprofitable option for many users [22]. 
There are many alternatives for determining the PV potential of a district. For instance, [26] presents a review of existing methods that aim at evaluating aspects such as passive heating and PV potential, [27] uses a combination of support vector machines and Geographic Information Systems (GIS) to estimate the PV potential for urban areas, or [28] design a novel method to obtain the optimum community energy storage systems for end user applications. In [29] the relevance of facades and other vertical features in the urban environment for solar power generation is analyzed. The study in [30] shows a method to conduct PV potential analyses in high detail using publicly available building data and aerial images in combination with image recognition techniques without having to rely on 3D model data. However, the use of 3D city models combined with simulation functionalities allows to quantify energy demand and renewable generation for very large set of buildings in a more accurate way, as it has been shown by studies such as [31-33].

Since PV systems supply power only during the day, which means only approximately half of the hours of the year, it is necessary to analyze when the power is supplied compared to the demanded load [34]. Demand patterns affect the optimal PV orientation, so choosing it should not only be based on maximizing energy production (as is frequent in most designs), but also on expected demand patterns and market prices [35]. Even in buildings with the same level of yearly generation and consumption, the mismatch between the demand and PV generation profiles leads to large power flows between the household and the grid, creating network problems and causing economic losses to the end-users [36]. The study in [22] showed that the aggregation of the demand and PV potential from different building surfaces in the urban context translates into a better demand-supply match, therefore minimizing storage needs. In addition, an analysis of the performance of a PV-Trombe wall studying the impact of several PV parameters on the electricity generation can be seen in [37], determining optimal tilt angles and suggesting how solar energy can be in charge of energy savings within a building.

Using a combination of air-conditioning use with the operation of time-shiftable appliances, [38] investigate the potential for residential consumers to lower community-level peak demand through home energy management systems. Another option to improve selfconsumption is rescheduling appliances, typically washing machines, clothes dryers and dishwashers. However, the main conclusion reached in [39] is that there is an overall small contribution when carrying out that approach, and that radically different market conditions would be needed to make them advantageous for the grid. [40] present a novel control algorithm for joint energy demand and thermal comfort optimization in PV microgrids. The study in [41] shows a novel control algorithm for joint demand response management and thermal comfort optimization in microgrids with renewable energies and storage. In [42], a novel method for quantifying the available demand flexibility of buildings is proposed, including a probabilistic analysis to specify the stochastic nature of energy demand, weather, construction type and comfort constraints.

\subsection{Aim of the study}

The case study of the present work is a social housing district of 235 households in the province of Seville, in southern Spain. The city where the district is located has an average income of $12900 €$ /household per year, and the unemployment rate is very high $(22.90 \%$ in January 2018). The climate is severe both in summer and winter and the thermal efficiency of the buildings is rather poor, thus the households that will be assessed are living in conditions of extreme energy poverty. A monitoring campaign was carried out during the whole year of 2017 , obtaining measurements of total electricity consumption and indoor temperature of the 
living room and a bedroom in 10 representative dwellings of the district at hourly intervals. The measurements revealed the unbearable temperatures that the occupants have to endure both in summer and winter, and the need for thermal comfort improvement measures.

It is very common to carry out thermal mitigation strategies by rehabilitating the existing building stock: increasing the thermal insulation, improving the thermal bridges or reducing the air infiltrations (winter), as well as using solar control strategies or night ventilation (summer). However, this work seeks to offer a different alternative, which could either substitute or, even better, work hand in hand with traditional retrofitting strategies.

The purpose of the present study is to assess the benefits of exploiting the rooftop PV potential of the district so as to improve the thermal comfort of the occupants and mitigate extreme low and high indoor temperatures, and at the same time reduce their energy bills. This will be done by using the solar PV generation to cover part of the district's energy consumption, and the rest of the electricity (which would otherwise be exported) to supply power for the heat pumps (HP) of the households in the district instead. In this way, rather than using electrical storage as is frequent in most studies, the present work takes advantage of the thermal mass storage capacity of the buildings themselves and at the same time improves the thermal comfort levels of the occupants. The thermal behavior of the buildings will be characterized by using very detailed simulation models of the 37 typologies in which the 235 dwellings of the buildings were categorized.

Several alternatives will be analyzed in energy and economic terms for exploiting the PV potential of the district, changing the orientation and inclination of the PV panels as well as the separation between adjacent rows. This will be done with the purpose of determining the optimal options regarding maximum PV production, maximum self-sufficiency ratio and minimum investment costs. Once the optimal PV strategies are detected, 5 different alternatives to share the available electricity surplus of the district will be considered to improve the thermal comfort of the occupants.

This paper is structured as follows. In Section 2, a description of the case study and the experimental measurements is presented, followed by the description of the proposed method and strategies. The analysis of results regarding the PV potential and thermal comfort improvement strategies is then discussed in Section 3. Finally, we conclude with a brief summary in Section 4. The current work aims to shed some light into whether it might be beneficial to install large PV systems in order to improve the thermal comfort in districts at risk of energy poverty.

\section{Case study: modelling and simulation}

\subsection{Description of the case study}

The social housing district under study is owned by the Agency for Housing and Rehabilitation in Andalusia (AVRA). It is composed of 235 dwellings distributed among the buildings in the area, which were built in 1983. The thermal envelope and windows have a poor quality (for instance $U_{\text {walls }}=1.77 \mathrm{~W} / \mathrm{m}^{2} \mathrm{~K}$ ). The district of 235 dwellings has been divided into 37 different typologies. This means that every dwelling in the district belongs to one of the typologies, which have been distinguished according to geometry of the dwelling, orientation and floor number. Table 1 shows a summary of the considered typologies. A representation of the district and some of the detailed building models created for the present study can be seen in 
219 Figure 1. As it can also be observed, the roofs of the buildings in the upper-right corner are 220 tilted, while the rest are flat.

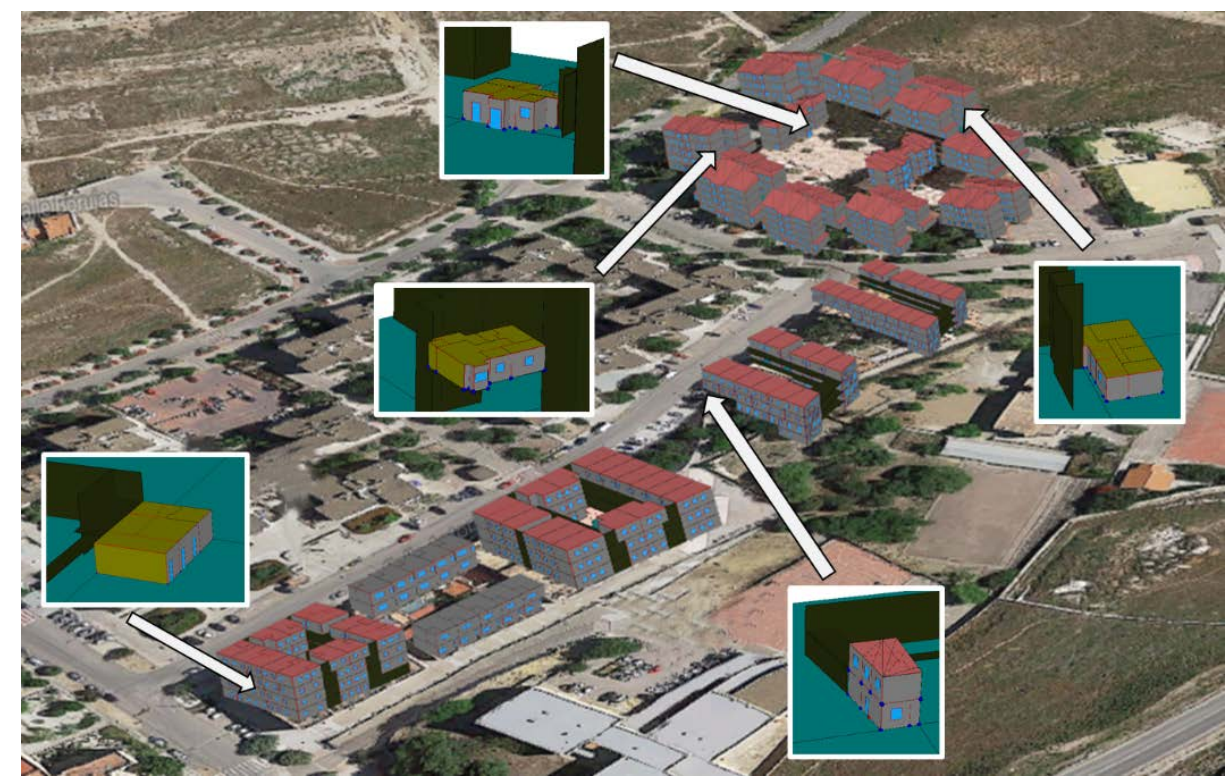

Figure 1: Representation of some of the detailed models in the district.

\begin{tabular}{|c|c|c|c|c|}
\hline TYPOLOGY & ORIENTATION & $\begin{array}{l}\text { AREA } \\
{[\mathrm{m} 2]}\end{array}$ & FLOOR & $\begin{array}{c}\text { NUMBER OF } \\
\text { DWELLINGS IN THE } \\
\text { DISTRICT }\end{array}$ \\
\hline TYPOLOGY 1 & SOUTH-WEST & 66 & GROUND FLOOR & 7 \\
\hline TYPOLOGY 2 & NORTH-WEST & 66 & GROUND FLOOR & 9 \\
\hline TYPOLOGY 3 & NORTH-EAST & 61 & GROUND FLOOR & 4 \\
\hline TYPOLOGY 4 & SOUTH-EAST & 61 & GROUND FLOOR & 2 \\
\hline TYPOLOGY 5 & SOUTH-WEST & 78 & INTERMEDIATE & 8 \\
\hline TYPOLOGY 6 & NORTH-WEST & 78 & INTERMEDIATE & 6 \\
\hline TYPOLOGY 7 & NORTH-EAST & 78 & INTERMEDIATE & 6 \\
\hline TYPOLOGY 8 & SOUTH-EAST & 78 & INTERMEDIATE & 9 \\
\hline TYPOLOGY 9 & SOUTH-WEST & 66 & INTERMEDIATE & 13 \\
\hline TYPOLOGY 10 & NORTH-WEST & 66 & INTERMEDIATE & 14 \\
\hline TYPOLOGY 11 & NORTH-EAST & 66 & INTERMEDIATE & 15 \\
\hline TYPOLOGY 12 & SOUTH-EAST & 66 & INTERMEDIATE & 14 \\
\hline TYPOLOGY 13 & SOUTH-WEST & 66 & UPPER FLOOR WITH ROOF & 9 \\
\hline TYPOLOGY 14 & NORTH-WEST & 66 & UPPER FLOOR WITH ROOF & 9 \\
\hline TYPOLOGY 15 & NORTH-EAST & 66 & UPPER FLOOR WITH ROOF & 4 \\
\hline TYPOLOGY 16 & SOUTH-EAST & 66 & UPPER FLOOR WITH ROOF & 4 \\
\hline TYPOLOGY 17 & $\begin{array}{l}\text { NORTH-WEST / } \\
\text { SOUTH-WEST }\end{array}$ & 56 & GROUND FLOOR & 2 \\
\hline TYPOLOGY 18 & $\begin{array}{l}\text { NORTH-EAST / } \\
\text { SOUTH-EAST }\end{array}$ & 56 & GROUND FLOOR & 2 \\
\hline TYPOLOGY 19 & $\begin{array}{l}\text { NORTH-WEST / } \\
\text { SOUTH-WEST }\end{array}$ & 56 & INTERMEDIATE & 2 \\
\hline TYPOLOGY 20 & $\begin{array}{c}\text { NORTH-EAST / } \\
\text { SOUTH-EAST }\end{array}$ & 56 & INTERMEDIATE & 2 \\
\hline TYPOLOGY 21 & $\begin{array}{l}\text { NORTH-WEST / } \\
\text { SOUTH-WEST }\end{array}$ & 56 & UPPER FLOOR WITH ROOF & 2 \\
\hline TYPOLOGY 22 & $\begin{array}{c}\text { NORTH-EAST / } \\
\text { SOUTH-EAST }\end{array}$ & 56 & UPPER FLOOR WITH ROOF & 2 \\
\hline
\end{tabular}




\begin{tabular}{|c|c|c|c|c|}
\hline TYPOLOGY 23 & NORTH-WEST & 75 & GROUND AND FIRST FLOOR & 3 \\
\hline TYPOLOGY 24 & NORTH-WEST & 75 & GROUND FLOOR & 2 \\
\hline TYPOLOGY 25 & NORTH-EAST & 57 & GROUND FLOOR & 2 \\
\hline TYPOLOGY 26 & NORTH-EAST & 65 & GROUND AND FIRST FLOOR & 2 \\
\hline TYPOLOGY 27 & NORTH-WEST & 75 & INTERMEDIATE FIRST FLOOR & 4 \\
\hline TYPOLOGY 28 & $\begin{array}{l}\text { SOUTH-EAST / } \\
\text { NORTH-EAST }\end{array}$ & 51 & INTERMEDIATE FIRST FLOOR & 2 \\
\hline TYPOLOGY 29 & $\begin{array}{l}\text { SOUTH-EAST / } \\
\text { NORTH-EAST }\end{array}$ & 52 & INTERMEDIATE SECOND FLOOR & 2 \\
\hline TYPOLOGY 30 & NORTH-WEST & 56 & INTERMEDIATE FIRST FLOOR & 6 \\
\hline TYPOLOGY 31 & NORTH-EAST & 75 & INTERMEDIATE FIRST FLOOR & 9 \\
\hline TYPOLOGY 32 & NORTH-WEST & 73 & $\begin{array}{l}\text { INTERMEDIATE + UPPER FLOOR } \\
\text { WITH ROOF }\end{array}$ & 23 \\
\hline TYPOLOGY 33 & NORTH-EAST & 73 & $\begin{array}{c}\text { INTERMEDIATE + UPPER FLOOR } \\
\text { WITH ROOF }\end{array}$ & 27 \\
\hline TYPOLOGY 34 & $\begin{array}{l}\text { NORTH-WEST / } \\
\text { NORTH-EAST }\end{array}$ & 64 & $\begin{array}{c}\text { INTERMEDIATE + UPPER FLOOR } \\
\text { WITH ROOF }\end{array}$ & 2 \\
\hline TYPOLOGY 35 & $\begin{array}{l}\text { NORTH-WEST / } \\
\text { SOUTH-EAST }\end{array}$ & 64 & $\begin{array}{c}\text { INTERMEDIATE + UPPER FLOOR } \\
\text { WITH ROOF }\end{array}$ & 2 \\
\hline TYPOLOGY 36 & $\begin{array}{l}\text { SOUTH-EAST / } \\
\text { NORTH-WEST }\end{array}$ & 64 & $\begin{array}{c}\text { INTERMEDIATE + UPPER FLOOR } \\
\text { WITH ROOF }\end{array}$ & 2 \\
\hline TYPOLOGY 37 & $\begin{array}{l}\text { SOUTH-EAST / } \\
\text { SOUTH-WEST }\end{array}$ & 64 & $\begin{array}{c}\text { INTERMEDIATE + UPPER FLOOR } \\
\text { WITH ROOF }\end{array}$ & 2 \\
\hline & & & & 235 \\
\hline
\end{tabular}

\section{$225 \quad 2.2$ Experimental measurements: justifying the need for intervention}

226 A monitoring campaign was designed to assess the level of indoor comfort in the district. Measurements were taken in 10 representative dwellings, recording the indoor air temperature every hour during the whole year 2017. On the other hand, household electricity consumption has a very strong temporal variation not captured with consumption data from monthly bills, so high-resolution data from smart meters is paramount. Therefore, the electric power consumption in each dwelling (D) was recorded through a smart meter every hour of the year, determining the total household electricity consumption. The characteristics of the chosen dwellings can be seen in Table 2 .

\begin{tabular}{|c|c|c|c|}
\hline Dwelling & Area [m2] & $\begin{array}{l}\text { Number of } \\
\text { occupants }\end{array}$ & Installed sensors \\
\hline D1 & 78 & 3 & \multirow{10}{*}{$\begin{array}{l}\text {-Smart meter. } \\
\text {-Living room } \\
\text { temperature. } \\
\text {-Bedroom } \\
\text { temperature. }\end{array}$} \\
\hline D2 & 78 & 5 & \\
\hline D3 & 56 & 4 & \\
\hline D4 & 56 & 1 & \\
\hline D5 & 75 & 4 & \\
\hline D6 & 73 & 4 & \\
\hline D7 & 56 & 3 & \\
\hline $\mathrm{D} 8$ & 73 & 3 & \\
\hline D9 & 66 & 1 & \\
\hline D10 & 73 & 7 & \\
\hline
\end{tabular}


For the whole period of the study, weather data is also available through a nearby weather station, providing hourly values of outdoor temperature, humidity, and solar radiation. The minimum outdoor air temperature (see Figure 2) was recorded on the $18^{\text {th }}$. of January $(-0.79$ ${ }^{\circ} \mathrm{C}$ ), while the higher temperature was recorded on the $13^{\text {th }}$ of July $\left(42.4^{\circ} \mathrm{C}\right)$.

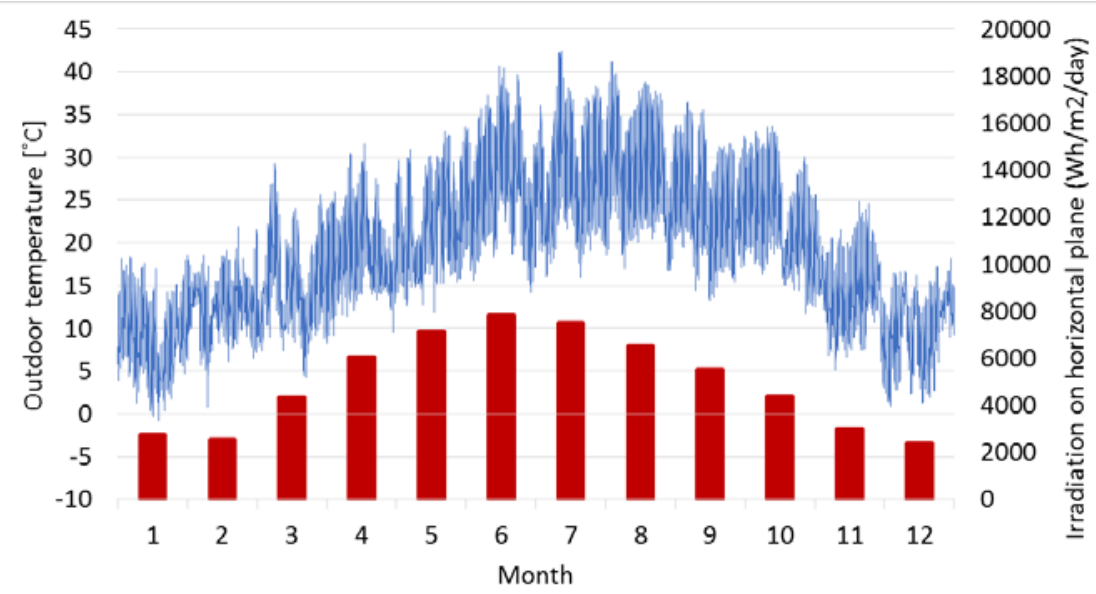

Since most of the studied dwellings were not air-conditioned, the indoor temperatures were persistently high or low for many days in a row. Door-to-door surveys revealed that some of the occupants even moved their cushions to the living room floor in summer, due to the unbearable temperatures in their bedrooms during the night which made it impossible to fall asleep.

Even though all the dwellings have a split air conditioner in the living room, most of them also have an electric stove under the living's room table, which is very frequent in Spain. Under the wrong assumption that using the stove incurs in lower costs, most of the dwellings do not make use of the split air conditioners in winter: either they don't use heating at all, or they only use the electric stoves. The hourly temperatures of the living rooms in the monitored dwellings can be seen in Figure 3. As shown, the indoor temperatures in all the dwellings are certainly far beyond the comfort zone most of the time, even though some of them make use of the split air conditioners for short periods.
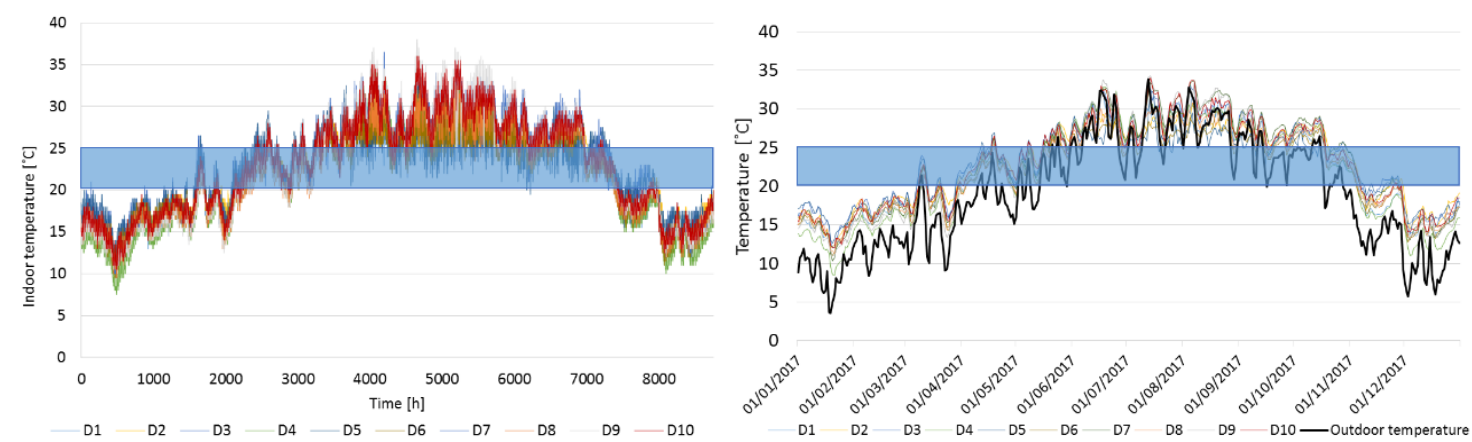

Figure 3: Hourly temperatures of the living rooms in the monitored households (left) and average daily temperatures (right).

On the other hand, the temperature of one bedroom in each monitored dwelling was also measured. In contrast with the measurements of the temperatures in the living rooms, it can 
be seen that none of the bedrooms in the dwellings are air-conditioned (see Figure 4). The differences between dwellings are mainly due to orientation (solar gains) and internal gains. The percentage of time outside the comfort zone in all the dwellings can also be seen in Figure 5. The results reveal the poor conditions in which the occupants of these households live, with several months in a row where the thermal comfort is violated $100 \%$ of the time.
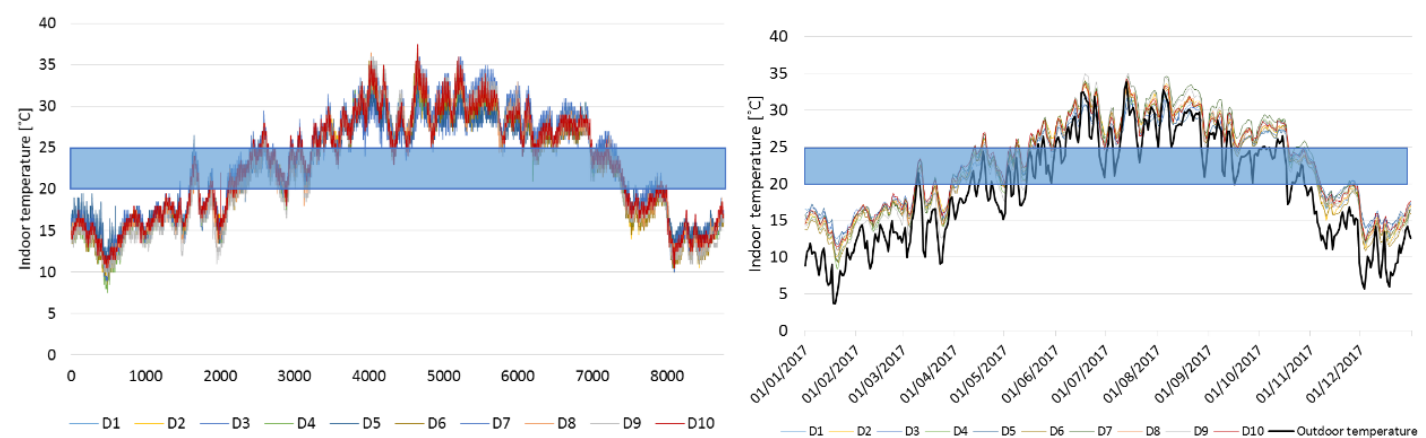

Figure 4: Hourly temperatures of the bedrooms in the monitored households (left) and average daily temperatures (right).

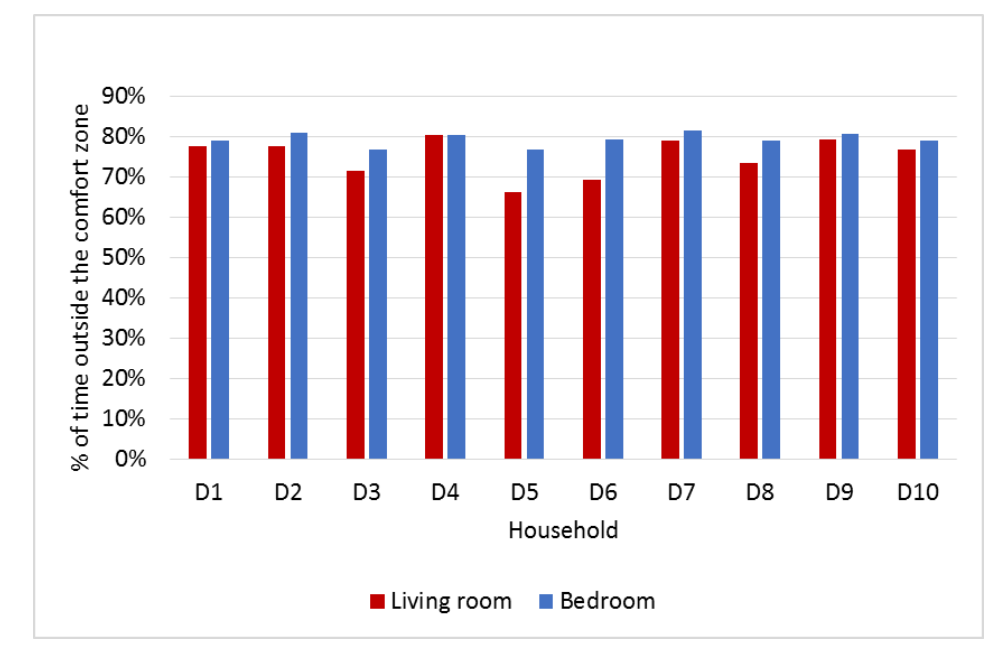

Figure 5: Percentage of time outside the comfort zone of all the households.

271 If we focus on individual dwellings, a clear difference can be observed between those whose 272 living room is air-conditioned, and those that make no use of heating or cooling. This can be seen in Figure 6, which shows the difference of temperatures between the living room and the bedroom in dwellings D6 and D7. While D6 uses the split air conditioner, D7 uses no heating or cooling whatsoever, which translates into very similar temperatures in both of its rooms. 

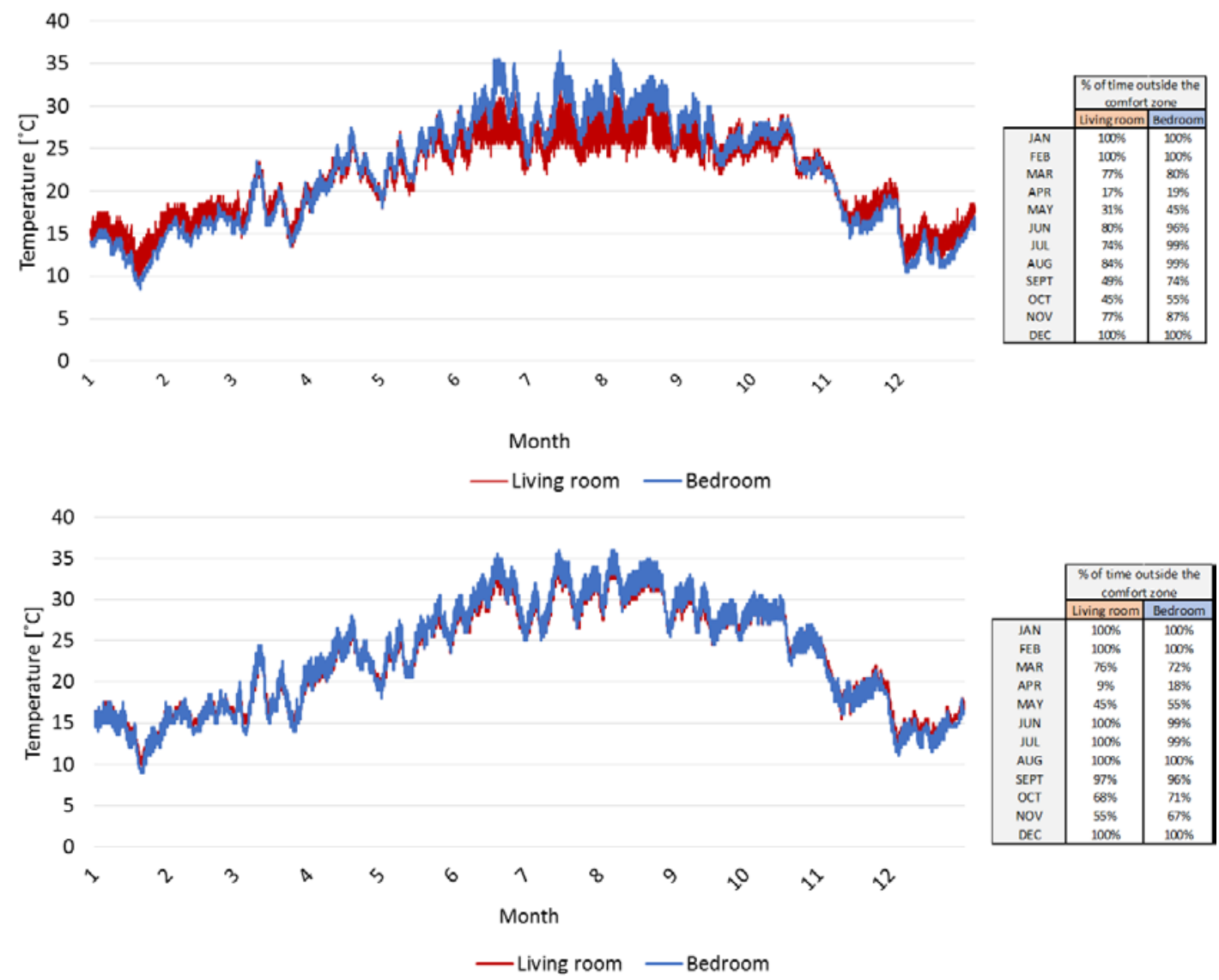

Figure 6: Comparison of temperatures in the conditioned household D6 (up) and the non-conditioned household D7 (down).

On the other hand, the household electricity consumption measured by the smart meters in each dwelling at hourly intervals allows to understand their behavior in a better way. One interesting outcome is to observe the relationship between the electricity consumption and the differences of temperature in the living room and bedroom of an air-conditioned household. Figure 7 shows such an example of this comparison. In this case, the household consumption has been filtered to show the hourly consumption values only if a difference of temperature of more than $1^{\circ} \mathrm{C}$ is observed between both rooms. As it can be seen, there is a clear correspondence between the energy consumption and the temperature increase in the living room.

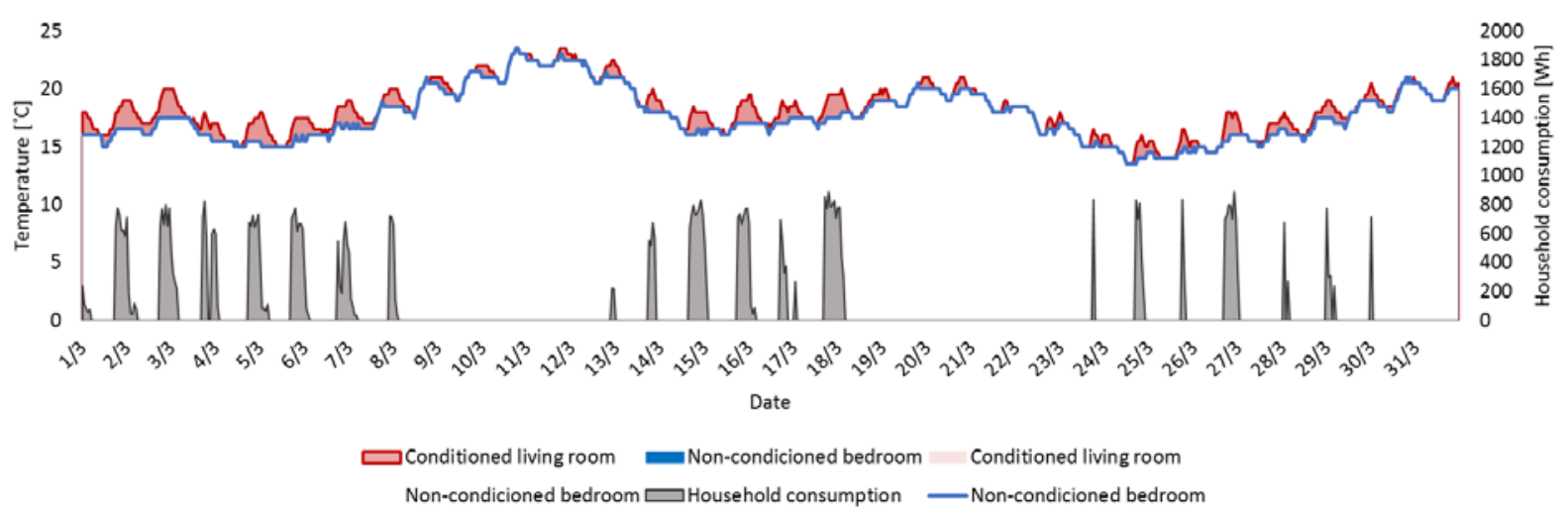

Figure 7: Hourly comparison of temperatures and consumption in dwelling D6. 
The monitoring of 10 representative dwellings allows to estimate the total electricity consumption of the district in an accurate way. As we aggregate different household electricity consumption profiles, the result for the district is a smoother profile whose shape will match better the PV generation. In order to show the measurements of the 10 dwellings, an average daily energy consumption profile per household in the district which accounts for all appliances and lighting consumptions in the dwellings has been produced, distinguishing between each month (see Figure 8). Peaks can be observed at lunch (around 15h) and dinner time (21-22h). These average profiles have been obtained considering only the consumption measurements in each individual dwelling when the difference between the temperatures in its two monitored rooms is lower than $1^{\circ} \mathrm{C}$, so as not to take into account hours with air conditioning consumptions.

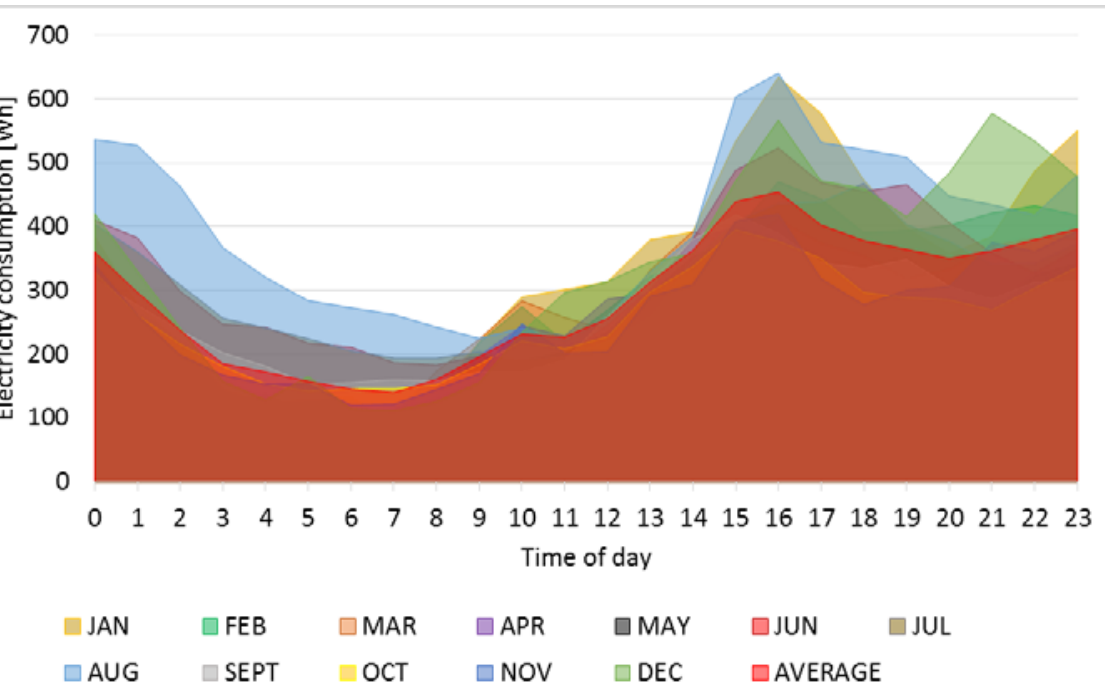

In order to calculate the total electricity consumption of the district (without taking airconditioning into account), the average consumption of the 10 monitored dwellings has been calculated for each hour of the year, discarding those consumptions when the difference of temperature between the monitored rooms of the household was higher than $1^{\circ} \mathrm{C}$. Once the average consumption is calculated each hour, the total consumption has been estimated by extrapolating the result to the whole district, composed of 235 buildings. The resulting hourly consumption profile of the district for the whole year is shown in Figure 9. 


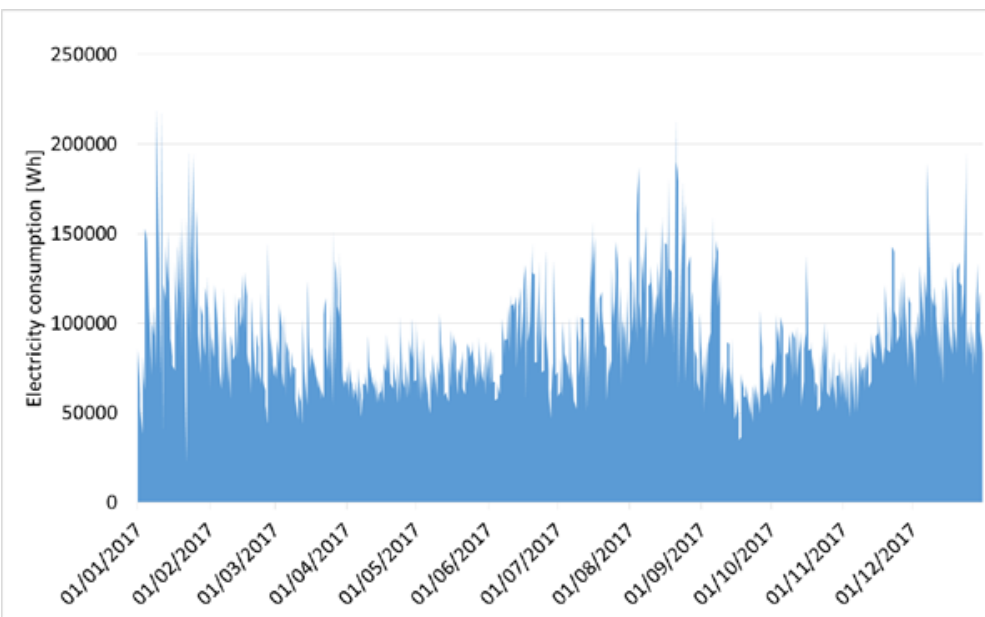

Figure 9: Electricity consumption of the district for every hour of the year.

\section{$314 \quad 2.3 \quad$ Methodological description}

315 From the point of view of the present work, the PV potential of the district could be used to 316 mitigate the consequences of low income and high energy prices on its inhabitants, which 317 restrict their energy consumption especially when it comes to heating or cooling the dwellings. 318 In this case, the solar power generation will be used to cover partially the electricity demand of 319 the district. No electrical storage will be considered.

320 If the PV generation is lower than the demand, then all the PV generation will be used and the rest of the electricity necessary to cover the demand of the district will be obtained from the grid at its regular price. Conversely, if the PV generation exceeds the demand there will be exported energy. Traditionally this is handled by using net metering, which allows users with surplus electricity to feed the electricity that they do not use back into the grid, obtaining benefits in the process. Given the intricate regulatory and practical situation in Spain in this respect, the proposal of this study is to use the electricity surplus to feed the heat pumps in the district instead. In this way, the thermal storage capacity of the buildings is used and the thermal comfort of the occupants can be improved. The control strategy of the proposed system is summarized in Figure 10. 


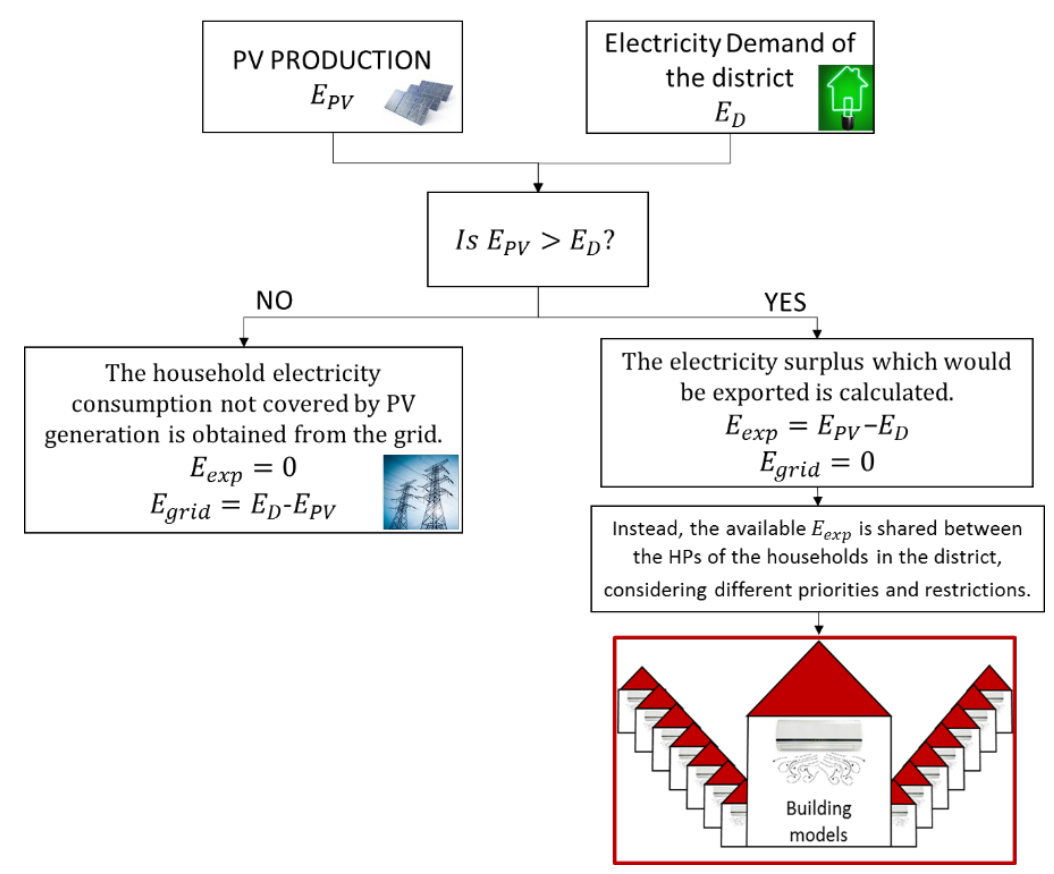

Figure 10: Control diagram of the proposed strategies.

332 On another note, two indicators will be used to analyze the match between the district's electricity consumption and the PV generation:

-Self-consumption ratio: share of the solar supply that is directly consumed in the district.

$$
S C R=\frac{\sum P V_{\text {production }}-\sum P V_{\text {exported }}}{\sum P V_{\text {production }}}
$$

-Self-sufficiency ratio: share of the district demand covered by the solar supply.

$$
S S R=\frac{\sum P V_{\text {production }}-\sum P V_{\text {exported }}}{\sum E_{D}}
$$

To determine the Life Cycle Costs (LCC) of each analyzed scenario, a time span which includes the capital investment, operation and maintenance costs was considered. The following parameters are used: investment period of 25 years, inflation rate of $3 \%$ and maintenance and costs of $1 \%$ of total investment of the project. The electricity cost from the grid is $0.209 € / \mathrm{kWh}$. The total investment costs are calculated by considering the price of the installed PV modules and inverters in each case. In addition, an increment of $40 \%$ will be considered so as to take into account other costs such as wiring or installation.

The values for the LCC were obtained with the following equation:

$$
L C C=\text { Initial }_{\text {investment }}+\left(\text { Costs }_{\text {operation }}+\text { Costs }_{\text {maintenance }}\right) \cdot \sum_{t=1}^{25} \frac{1}{(1+r)^{t}}
$$

where " $\mathrm{t}$ " is the year, and " $\mathrm{r}$ " is the inflation rate.

345 The PV modules chosen for the present study are the model Atersa A-250P (250W), and the 346 inverters are Fronius Eco 25.0-3-s $(25 \mathrm{~kW})$, with costs of 182 Euros and 3690 Euros 347 respectively. 


\subsection{PV potential simulation}

Although the PV potential of a district is frequently estimated through the use of 3D models for example, the relatively simple layout of the case study in the present work allowed to design the PV system in a simpler but also more detailed way. This was done by using Helioscope [43], a web-based PV system design tool that integrates shading analysis, simulation and CAD in one package. It allows to estimate the yearly energy production taking into account losses due to weather, shading, wiring, component efficiencies, panel mismatches and aging. It provides recommendations for equipment and array layout, and the discrete number of PV modules that can fit into a solar field is calculated, considering parameters such as the orientation and inclination of the modules or the separation between adjacent rows.

It should be mentioned that the buildings of the district which have tilted roofs (see Figure 1) will not be used to install PV modules, since the presence of solar thermal panels as well as other obstacles does not allow it. Considering, therefore, only the flat roofs, an example of a PV layout in the district under study using Helioscope can be seen in Figure 11. Since all the buildings have the same height, shading due to distant objects was not considered, only shading between the own PV modules. The total roof area of the district is $2300 \mathrm{~m}^{2}$. approximately.

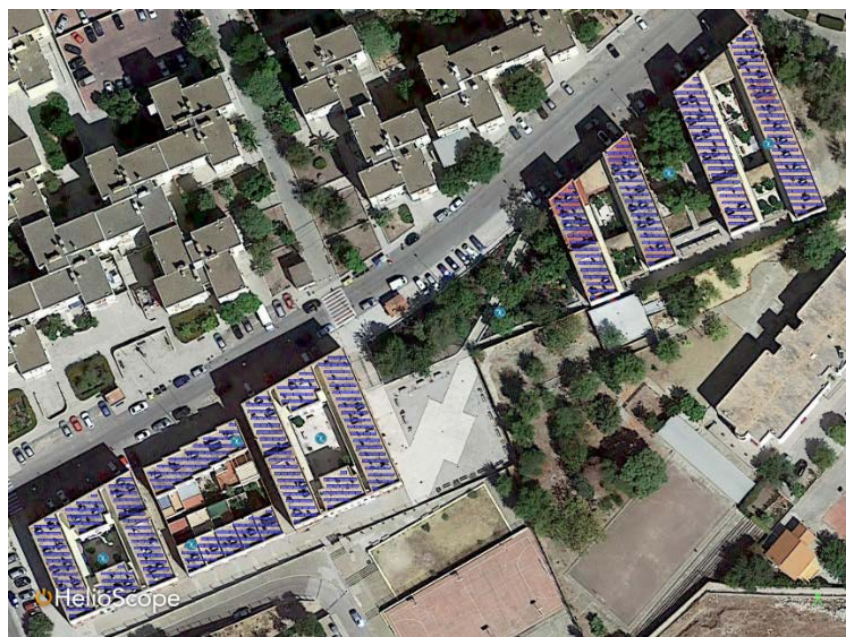

Figure 11: Example of layout of the district in Helioscope: south orientation in the flat roofs.

Although the PV modules are usually oriented to maximize the annual solar power supply, this may not optimize other indicators such as self-consumption, grid imported electricity or revenue. Thus, the present study varies the tilt and azimuth of the PV modules installed in the horizontal rooftops of the district, so as to assess in detail the match between the solar power supply and the electricity consumption of the district as well as evaluate different alternatives that will entail different PV yields in summer and winter (which will in turn influence the improvement of the thermal comfort of the occupants). Apart from varying the tilt and orientation of the PV modules, it is also interesting to evaluate the influence of the separation between rows in the horizontal rooftops of the district. This is done in Helioscope through the use of the span-to-rise ratio, which is based on the front-to-back distance between modules divided by the height at the back of the module bank. Therefore, this ratio is sensitive to whether the bank has multiple modules and the tilt of the module, since either of these will increase the rise distance. Raising the span-to-rise ratio increases the distance between rows, thus less PV modules will be installed, reducing the PV yield. However, increasing the ratio also 
reduces the shading losses, so various alternatives should be analyzed when focusing on maximizing the PV potential.

\subsection{Thermal behavior of the dwellings}

In order to analyze the thermal behavior of the district in detail, a building model for each of the 37 typologies has been developed. This means that a model with an accurate consideration of the geometry, materials, orientation, exposed surfaces of ceilings, walls, and floors is available for each of the 235 dwellings. The dwelling models were developed in the detailed Unified LIDER-CALENER software tool (HULC by its Spanish acronym), which is the official building energy certification tool in the country [44]. The real constructive solutions were used.

The reason for using this software is twofold: first, this tool follows a transient and hourly base assessment that has been validated via the Bestest [45], it has been used to obtain the Building Energy Performance Certificate of hundreds of thousands of buildings in Spain, and it has also been used by many studies in the recent literature [46-53]. And second, this tool was developed within the research group of the authors of the present work, which allowed to make certain modifications so as to be able to carry out the present study. As an example, a validation of the model of dwelling D4 (which corresponds to Typology 22) is presented in Figure 12, which compares the real measurements of the dwelling in 2017 with the simulation results of its free-floating temperature (no air conditioning system) when using the real climatic data. As it can be seen, the results provided by the software are highly accurate.

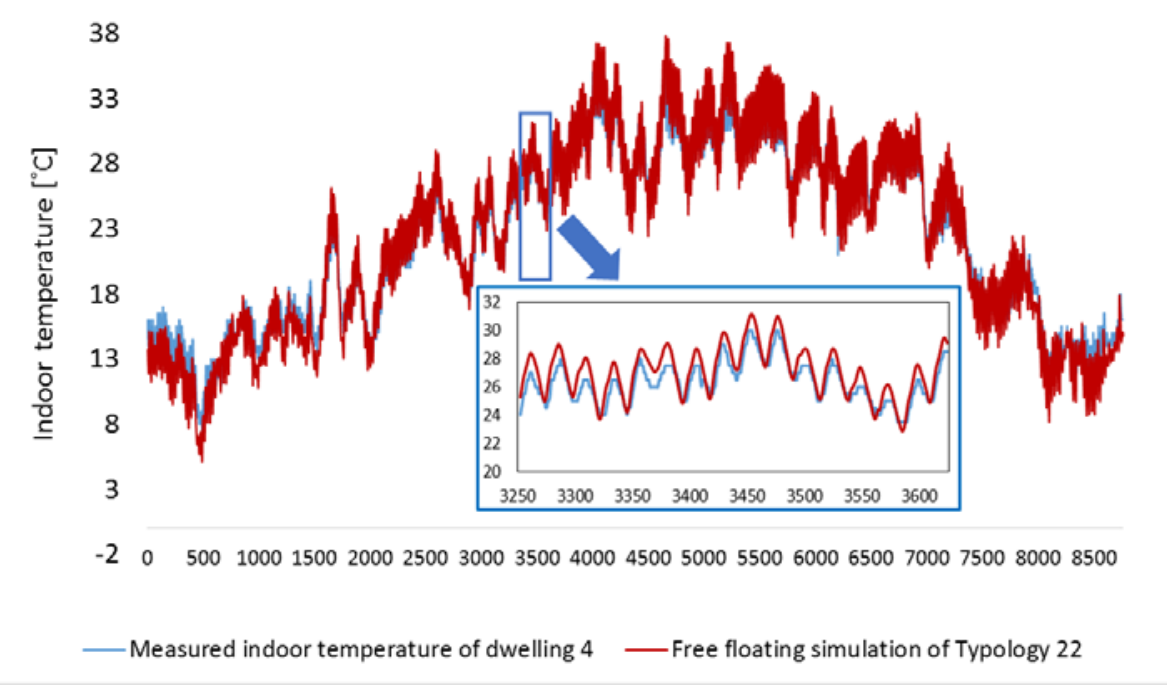

Figure 12: Validation with HULC of the measured indoor temperature of dwelling 4 for the whole year.

\subsection{Description of the proposed strategies}

\subsubsection{Optimal PV potential strategies}

In the present work, different alternatives that influence the PV production will be analyzed using the buildings with horizontal roofs. Many studies carry out a very detailed analysis for the optimization of the orientation and the tilt angle of the PV modules. For example, a very interesting review of tilt and azimuth angles considering design parameters, simulations and mathematical techniques for different applications can be seen in [54]. Other studies such as [55-57] determine the optimum tilt angles and orientation for solar photovoltaic arrays, in order to maximize incident solar irradiance for specific periods or latitudes. However, the 
present work reduced the amount of possibilities considered to 3 different tilt angles and 4 different orientations, since a detailed optimization was not its primary objective.

The options considered for the inclination of the PV modules are: latitude $-10^{\circ}$, latitude $+0^{\circ}$ and latitude $+10^{\circ}$. For the PV module orientation, the following options (which adapt to the shape of the roofs) will be studied:

- North-East orientation of the PV modules $\left(66^{\circ}\right)$.

- South-East orientation of the PV modules $\left(156^{\circ}\right)$.

- South orientation of the PV modules $\left(180^{\circ}\right)$.

- South-West orientation of the PV modules $\left(246^{\circ}\right)$.

Two alternatives for module spacing will be also used: span-to-rise $=1.5$ and span-to-rise $=2$, to check whether it is better to increase the distance between rows (less PV modules installed but reduced shading losses) or not. The proposed alternatives will be analyzed with the aim of estimating their effect on the following variables:

- Number of panels that can be installed.

- Annual/winter/summer solar energy supply.

- Matched electricity consumption.

- Self-consumption ratio.

- Self-sufficiency ratio.

- Life Cycle Cost.

Once all the alternatives have been examined, three of them will be chosen regarding the following criteria: maximization of self-sufficiency (SSF), maximization of exported PV production (SUPPLY) and minimization of the investment costs (INV). This will be done focusing only on the PV production and electricity demand of the district.

\subsubsection{Thermal comfort strategies}

The previously mentioned chosen strategies will be then used for the thermal comfort improvement analysis of the dwellings, using weather data of a representative year. However, one question that should be answered is the following: if there is surplus production (exported energy), who should benefit from the available electricity? This study does not seek to propose a detailed course of action regarding this issue (just like sharing in the reality the PV production between dwellings with different electricity consumptions), since it would be a task for studies with different purposes.

Bearing in mind that the focus is on quantifying the improvement of the thermal comfort of the occupants in the district, the following strategies are proposed:

- All the 235 dwellings in the district receive the same amount of electricity to feed their heat pumps (proportional). An indoor temperature restriction is considered: the heat pump of a dwelling can only be used at any time of the simulation if the thermal comfort of the occupants is guaranteed $\left(20-25^{\circ} \mathrm{C}\right)$. If this condition is not fulfilled, the energy that this dwelling would receive is shared by the remaining dwellings instead. If all the 235 dwellings have already been considered in a certain timestep and there is still a surplus, it will be quantified. This strategy will be named as "Prop".

- A fixed amount of electricity (500 Wh or $1000 \mathrm{Wh}$ ) is used to feed the heat pump of each dwelling. In this case, the number of dwellings $n_{\text {HP }}$ that can be fed considering 
the available electricity is calculated at the beginning of each timestep, and the $\mathrm{n}_{\mathrm{HP}}$. buildings with the lowest indoor temperature (in winter) or highest indoor temperature (in summer) will activate their heat pumps. The same indoor temperature restrictions as for the first strategy are considered. These strategies will be named as " $\mathrm{Q}=500$ " and " $\mathrm{Q}=1000$ ".

- The indoor temperature of all the dwellings in the district is checked at the beginning of the timestep. First, the dwelling with the lowest indoor temperature in winter (or highest in summer) is heated until reaching a certain set-point temperature. The necessary consumption in order to do so is accounted for. Then, the next dwelling is chosen and so on, until all the exported PV electricity has been used. Two options will be considered: one with a set-point temperature of $25{ }^{\circ} \mathrm{C}$ in winter and $20{ }^{\circ} \mathrm{C}$ in summer, and another one with $22.5^{\circ} \mathrm{C}$ for both summer and winter periods. These strategies will be named as " $\mathrm{T}=20 / 25^{\prime}$ and " $\mathrm{T}=22.5$ ".

In summary, these 5 thermal comfort improvement strategies will be simulated for each of the chosen optimal PV strategies (maximization of self-sufficiency, maximization of exported PV production and minimization of the investment costs), making a total of 15 alternatives. An average Coefficient of Performance (COP) of 2 will be considered for all the heat pumps in the district, which is a rather conservative value. Then, several indicators will be shown so as to make a proper performance assessment and comparison between the different options. The total excess degree hours for example will account for the sum of temperature differences in the whole season between the indoor temperature and the comfort temperature (below $20^{\circ} \mathrm{C}$ in winter and above $25^{\circ} \mathrm{C}$ in summer).

\section{Analysis of results}

\subsection{PV potential calculations}

Once all the PV potential calculations proposed in the previous section have been completed in Helioscope, the next step is to calculate all the variables involved. The number of PV modules that can be installed in the district is provided by the software, as well as the installed power and the solar power supply, calculated for every hour of the year. The annual results can be seen in Figure 13, with colors that highlight the best alternatives in each column independently. 


\begin{tabular}{|c|c|c|c|c|c|c|c|c|c|c|c|c|c|c|c|c|}
\hline ALTERNATIVE & $\begin{array}{l}\text { PV MODULE } \\
\text { ORIENTATION } \\
\text { IN FLAT ROOFS }\end{array}$ & $\begin{array}{l}\text { PV MODULE } \\
\text { INCLNATION IN } \\
\text { FLAT ROOFS }\end{array}$ & $\begin{array}{l}\text { SPAN- } \\
\text { TO-RIIE } \\
\text { RATIO }\end{array}$ & \begin{tabular}{|c|c} 
Number \\
of fP \\
modules
\end{tabular} & $\begin{array}{c}\text { Installed } \\
\text { power } \\
{[\mathrm{kWp}]}\end{array}$ & $\begin{array}{l}\text { Investment } \\
\text { [Euros] }\end{array}$ & $\cos t / k W p$ & $\begin{array}{c}\text { Annual solar } \\
\text { power supply } \\
\text { [MWh] }\end{array}$ & $\begin{array}{l}\text { Grid } \\
\text { import } \\
\text { [MWh] }\end{array}$ & \begin{tabular}{|l} 
Matched \\
electricity \\
[MWh/yr]
\end{tabular} & $\begin{array}{c}\text { Annual } \\
\text { exported } \\
\text { electricity } \\
\text { [MWh] } \\
\end{array}$ & $\begin{array}{c}\text { Winter } \\
\text { exported } \\
\text { electricity } \\
\text { [MWh] }\end{array}$ & \begin{tabular}{l|} 
Summer \\
exported \\
electricity \\
[MWh]
\end{tabular} & LCC $[k €]$ & $\begin{array}{c}\text { Self-cons. } \\
\text { ratio }\end{array}$ & $\begin{array}{c}\text { Self-suff. } \\
\text { ratio }\end{array}$ \\
\hline Base case & & & & 0 & 0 & 0 & 0 & 0 & 600 & 0 & 0 & 0 & 0 & 2185 & 0.0 & $0.0 \%$ \\
\hline 1 & NORTH-EAST & LATITUDE + 10 & 1.5 & 885 & 221 & 261923 & 1184 & 204 & 477 & 124 & 81 & 36 & 44 & 2043 & $60.5 \%$ & $20.6 \%$ \\
\hline 2 & NORTH-EAST & LATITUDE + 10 & 2 & 824 & 206 & 246411 & 1196 & 223 & 467 & 133 & 90 & 37 & 53 & 1989 & $59.8 \%$ & $22.2 \%$ \\
\hline 3 & NORTH-EAST & LATITUDE & 1.5 & 939 & 235 & 280862 & 1196 & 271 & 445 & 155 & 116 & 50 & 67 & 1950 & $57.2 \%$ & $25.9 \%$ \\
\hline 4 & NORTH-EAST & LATITUDE & 2 & 839 & 210 & 250187 & 1193 & 244 & 452 & 149 & 95 & 41 & 54 & 1937 & $61.0 \%$ & $24.8 \%$ \\
\hline 5 & NORTH-EAST & LATITUDE - 10 & 1.5 & 1053 & 263 & 309946 & 1177 & 340 & 418 & 182 & 149 & 70 & 79 & 1886 & $53.6 \%$ & $30.3 \%$ \\
\hline 6 & NORTH-EAST & LATITUDE - 10 & 2 & 861 & 215 & 255800 & 1188 & 262 & 436 & 164 & 98 & 45 & 52 & 1888 & $62.7 \%$ & $27.3 \%$ \\
\hline 7 & SOUTH-EAST & LATITUDE + 10 & 1.5 & 848 & 212 & 252534 & 1191 & 326 & 406 & 194 & 132 & 78 & 54 & 1775 & $59.5 \%$ & $32.3 \%$ \\
\hline 8 & SOUTH-EAST & LATITUDE + 10 & 2 & 720 & 180 & 214716 & 1193 & 289 & 414 & 186 & 103 & 62 & 41 & 1759 & $64.5 \%$ & $31.0 \%$ \\
\hline 9 & SOUTH-EAST & LATITUDE & 1.5 & 723 & 181 & 220593 & 1220 & 336 & 400 & 201 & 135 & 82 & 53 & 1714 & $59.7 \%$ & $33.4 \%$ \\
\hline 10 & SOUTH-EAST & LATITUDE & 2 & 723 & 181 & 215430 & 1192 & 295 & 409 & 191 & 104 & 64 & 39 & 1743 & $64.8 \%$ & $31.8 \%$ \\
\hline 11 & SOUTH-EAST & LATITUDE - 10 & 1.5 & 945 & 236 & 282393 & 1195 & 392 & 387 & 213 & 179 & 98 & 80 & 1740 & $54.4 \%$ & $35.5 \%$ \\
\hline 12 & SOUTH-EAST & LATITUDE - 10 & 2 & 835 & 209 & 249167 & 1194 & 353 & 394 & 207 & 146 & 81 & 64 & 1725 & $58.7 \%$ & $34.5 \%$ \\
\hline 13 & SOUTH & LATITUDE + 10 & 1.5 & 797 & 199 & 239472 & 1202 & 326 & 398 & 202 & 125 & 71 & 54 & 1731 & $61.8 \%$ & $33.6 \%$ \\
\hline 14 & SOUTH & LATITUDE + 10 & 2 & 661 & 165 & 199613 & 1208 & 285 & 408 & 192 & 93 & 52 & 41 & 1720 & $67.5 \%$ & $32.0 \%$ \\
\hline 15 & SOUTH & LATITUDE & 1.5 & 852 & 213 & 253555 & 1190 & 342 & 392 & 208 & 134 & 77 & 57 & 1726 & $60.9 \%$ & $34.6 \%$ \\
\hline 16 & SOUTH & LATITUDE & 2 & 852 & 213 & 248392 & 1166 & 299 & 401 & 200 & 99 & 59 & 41 & 1749 & $66.8 \%$ & $33.3 \%$ \\
\hline 17 & SOUTH & LATITUDE - 10 & 1.5 & 884 & 221 & 261719 & 1184 & 344 & 388 & 212 & 132 & 81 & 51 & 1719 & $61.7 \%$ & $35.4 \%$ \\
\hline 18 & SOUTH & LATITUDE - 10 & 2 & 775 & 194 & 233859 & 1207 & 346 & 392 & 209 & 137 & 73 & 64 & 1700 & $60.3 \%$ & $34.8 \%$ \\
\hline 19 & SOUTH-WEST & LATITUDE + 10 & 1.5 & 903 & 226 & 271678 & 1203 & 293 & 402 & 199 & 94 & 51 & 43 & 1782 & $67.8 \%$ & $33.1 \%$ \\
\hline 20 & SOUTH-WEST & LATITUDE + 10 & 2 & 828 & 207 & 247432 & 1195 & 254 & 410 & 190 & 64 & 39 & 24 & 1784 & $74.8 \%$ & $31.6 \%$ \\
\hline 21 & SOUTH-WEST & LATITUDE & 1.5 & 777 & 194 & 244695 & 1260 & 304 & 393 & 208 & 96 & 61 & 35 & 1716 & $68.4 \%$ & $34.6 \%$ \\
\hline 22 & SOUTH-WEST & LATITUDE & 2 & 777 & 194 & 234370 & 1207 & 282 & 399 & 202 & 80 & 47 & 33 & 1727 & $71.5 \%$ & $33.6 \%$ \\
\hline 23 & SOUTH-WEST & LATITUDE - 10 & 1.5 & 1064 & 266 & 312803 & 1176 & 376 & 380 & 220 & 156 & 84 & 71 & 1751 & $58.6 \%$ & $36.7 \%$ \\
\hline 24 & SOUTH-WEST & LATITUDE - 10 & 2 & 872 & 218 & 258657 & 1186 & 291 & 393 & 207 & 84 & 51 & 33 & 1735 & $71.2 \%$ & $34.5 \%$ \\
\hline
\end{tabular}

Figure 13: Obtained results in all the analyzed strategies. In each column, green cells represent the best options while red cells represent the worst ones. The marked alternatives are those chosen for the thermal comfort study.

First of all, it should be mentioned that choosing the optimal parameters is paramount in order to maximize the solar supply, which varies up to $48 \%$ among the studied alternatives. On the other hand, the differences between them regarding grid import, matched electricity and selfsufficiency ratio are not very significant. The reason behind this is that the electricity consumption of the social housing district is low, especially when compared to the PV generation obtained during sunshine hours after the installation of the PV modules. Remembering that the exported energy and its potential revenue is not being computed in these calculations for the reasons noted above, the considered alternatives still show payback periods around 7 years. Other conclusions that may be reached are mentioned below:

- The base case, which considers the provision of all electricity from the grid, is the one with the highest LCC.

- A lower inclination angle of the PV modules leads to more modules being installed, since the separation between rows is less restrictive. The north-east and south-west orientations also favor the number of modules that can be installed due to the shape of the roofs. The same happens with the span-to-rise ratio: the simulations with a value of 1.5 allow the installation of more modules. In most cases this results in an increase of the solar power supply, but also an increase on the LCC. The reason is that although more PV panels are installed, the shading losses increase if a span-to-rise ratio of 1.5 is used. Therefore, the results need to be carefully analyzed in order to choose the optimal options.

- In most cases, the maximum power supply in summer and annually is achieved with an inclination of latitude- $10^{\circ}$.

- In general, using the PV layouts with the north-east orientation results in less annual solar power supply as well as matched generation, exported electricity and selfsufficiency ratio. In addition, they are the ones with worse LCCs.

- The matched electricity and self-sufficiency ratio is higher when the south-west layout orientation is used (thus the grid import is lower in these cases). The reason is that the electricity demand of the district is higher after midday, favoring the south-west orientations which generate more energy during those periods. 
After considering in detail all the results from the PV alternatives that have been analyzed, three of them have been chosen for the thermal comfort study (see Figure 13):

- Alternative 11: it was selected since it offers the highest solar power supply both in summer and winter.

- Alternative 14: it has the lowest investment cost and almost the lowest LCC, since it is the alternative with the lowest number of PV modules installed. This option is optimal from an economic point of view, but offers a lower solar power supply.

- Alternative 23: it shows the highest self-sufficiency ratio and matched electricity, as well as the lowest grid import. This is due to the fact that it is the option with more PV modules installed (and higher investment costs).

\subsection{Thermal comfort improvement of the chosen strategies}

As mentioned in Section 2.6.2, the three optimal PV strategies that have been selected will be now used to analyze the potential benefits of using their exported PV production so as to improve the thermal comfort of the occupants, considering five different alternatives. Therefore, a total of 15 simulations will be conducted. Each simulation analyzes on an hourly basis the thermal behavior of each of the 235 dwellings during the 8760 hours of the year. The decision of which heat pumps should be activated, which depends on the strategy, is taken every timestep. As an example, Figure 14 illustrates simulated indoor temperatures and consumptions in dwelling 130 for some of the analyzed strategies in the PV optimal case that maximizes the exported PV production (SUPPLY). It can be seen how during the day, the exported PV production (Q) given to this dwelling is used to supply heat, which results in an increase of the indoor temperatures. It can also be seen how on the 21 of March this dwelling was not chosen for the strategy $T=20 / 25$, since other dwellings of the district had a higher priority due to their lower indoor temperatures. Once all the alternatives have been simulated, several indicators are calculated.

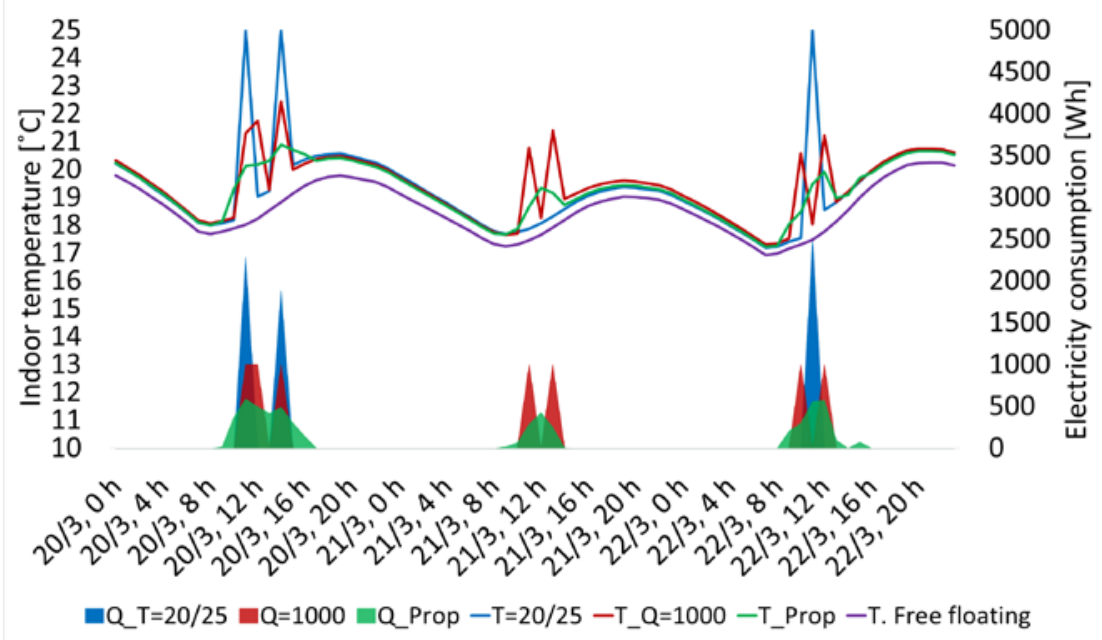

Figure 14: Example of simulated indoor temperatures and consumptions in the dwelling 130 for some of the analyzed strategies (case maximization of exported PV production).

The energy storage capacity of the structural mass becomes clear (see Figure 15) when the indoor temperature fluctuation under full free floating conditions (purple curve) and the indoor temperature fluctuation when the heat pump operates (green curve) are compared. The effect of the thermal mass is proportional to the difference between both curves when the 
547 heat pump is switched off (shaded area). It can be seen how this difference is obviously higher 548 in hours immediately after the heat pump operation.

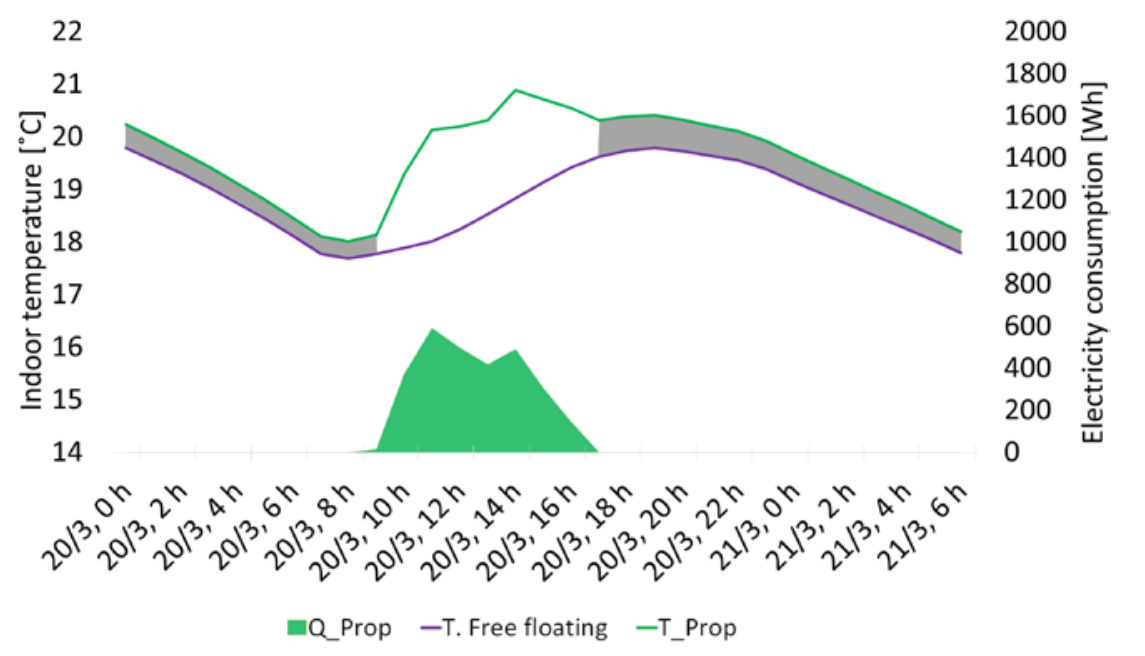

551 The results of all the strategies are given in Table 3, which shows among others the average 552 total excess degree hours and average percentage of time outside the comfort zone of the 553 dwellings in the district for each alternative. First of all, as we can see the three PV optimal 554 strategies (SUPPLY, INV and SSF) have a different amount of available electricity, which 555 influence the thermal comfort improvements. The percentage of energy used is computed in 556 each simulation. This indicates the amount of available electricity that has been used during 557 the whole year in the heat pumps of the district. A $100 \%$ is never achieved, since it could 558 happen that during a certain timestep all the buildings have already been heated/cooled and 559 there is still surplus electricity, for example if $Q=500 \mathrm{Wh}$ and the $\mathrm{PV}$ production is higher than $560117500 \mathrm{Wh}$, or if the temperature requirements of the strategies are not met so the dwelling 561 cannot be used. The number of activated dwellings varies depending on the followed strategy, 562 and the highest values can be found for the strategy "PROP", since there are no priorities to 563 heat/cool the dwellings and the same amount of energy is given to each of them.

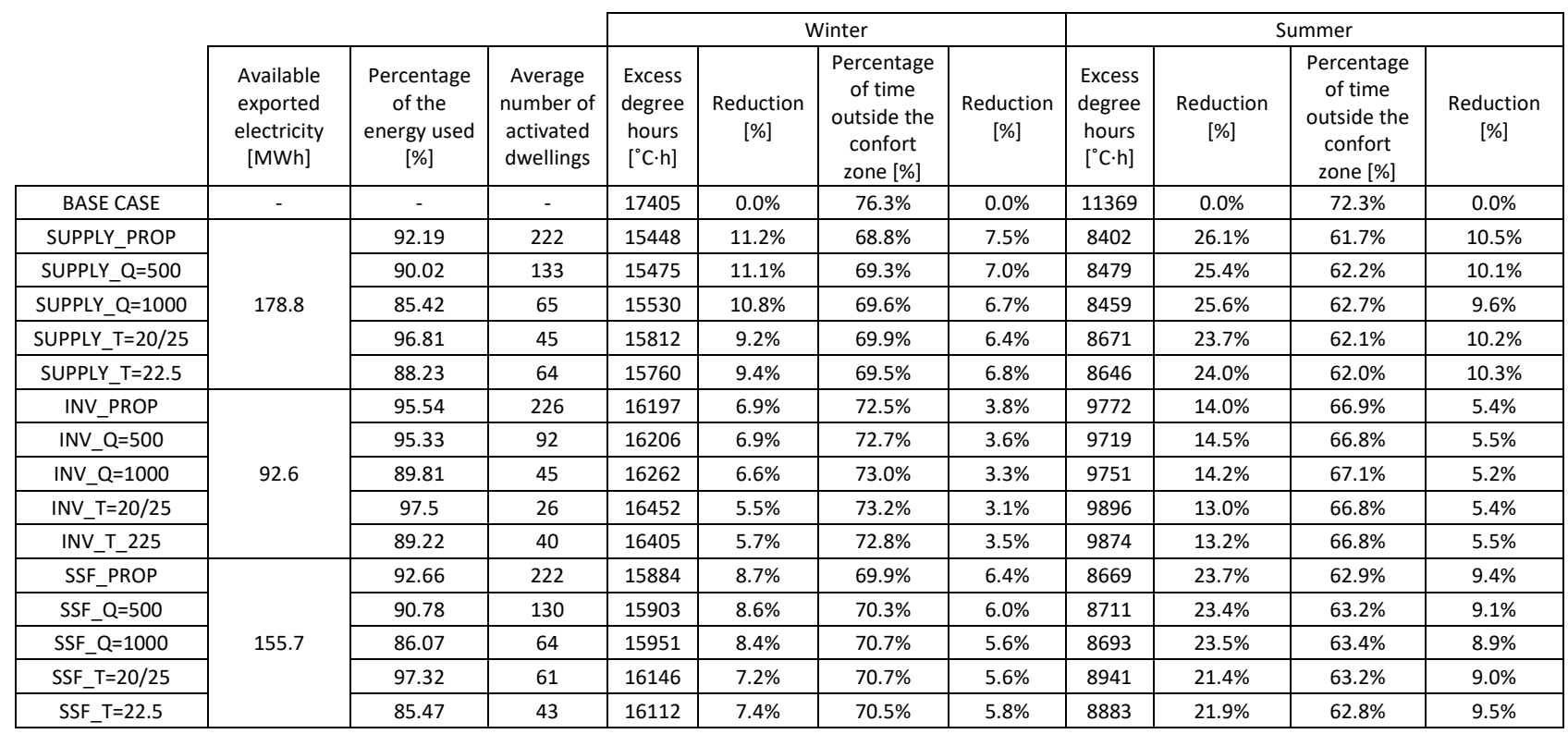


566

567

568

569

570

571

572

573

574

575

576

577

578

579

580

581

582

583

584

585

586

587

588

589

590

591

592

593

594

595

596

597

The highest reduction of total excess degree hours is found for the case "SUPPLY_PROP" (optimal PV case that maximizes the exported PV production, and shares the available energy between all the dwellings equally). The reason is that compared to the other strategies, the increase of temperatures produced by the heat pumps in the dwellings is lower, which translates into lower thermal losses. If a dwelling is heated/cooled only sporadically, the energy will be wasted rapidly. But, if a dwelling is repeatedly used, its thermal inertia allows to store the energy in a more adequate way. A $11.2 \%$ reduction of the total excess degree hours in winter and $26.1 \%$ in summer (more available electricity) may be achieved, reducing the percentage of time outside the comfort zone in $7.5 \%$ and $10.5 \%$ respectively. Although these results may not seem very appealing, the influence that these reductions of total excess degree hours have on the health of the occupants should be taken into account, since illnesses are associated with higher thermal comfort violations as mentioned in the literature review in Section 1.

Besides, these results could be rather misleading. Although it is true that the strategy "PROP" is the best alternative when looking at the whole district, the electricity in this case is shared equally between all the buildings. This means that for example a dwelling with better solar access than another one is given the same amount of energy. Therefore, although when looking at the whole district the average total excess degree hours is lower in "PROP", the dwellings with worse indoor conditions do not have a higher priority. Figure 16 shows the range of total excess degree hours of all the dwellings in the district for each strategy in the case "SUPPLY", as well as their distribution, which is similar in the studied alternatives. As it can be seen, although the average of the district in the case "PROP" is lower, there are buildings with much higher total excess degree hours compared to the other alternatives. For this reason, the alternative $\mathrm{T}=20 / 25$ is considered as a more suitable option, since it is also able to reduce the differences of thermal comfort between the dwellings of the district, favoring those which have worse indoor conditions.

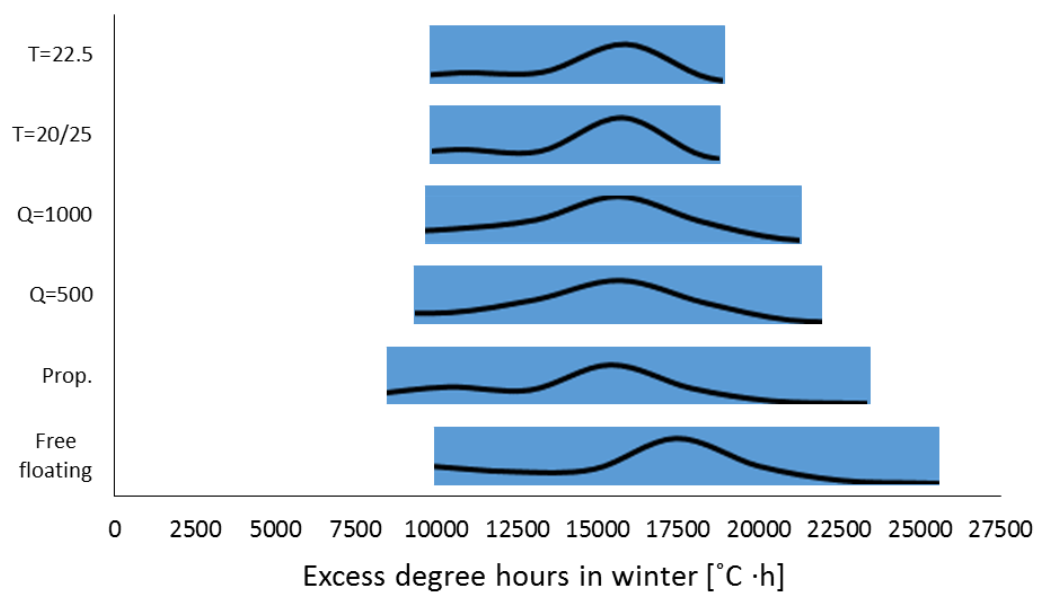

Figure 16: Comparison of total excess degree hours of the households for each strategy (case maximization of exported PV production).

Last of all, another interesting outcome of the present study is to know what the results of thermal comfort improvement would be, had the assumptions been different. The strategy $\mathrm{T}=20 / 25$, considered as a consequence of the previous results as the most appropriate one to 
620

621

622

623 reduce the differences of thermal comfort in the district, will be used in the following scenarios:

- Only the living rooms will be considered, instead of heating/cooling the whole dwellings. The PV production still covers the district demand partially just like in previous cases.

- All the electricity generated by the PV modules will be used for the heat pumps instead of covering partially the electricity demand of the district, heating or cooling the whole dwellings.

- The potential PV generation if the buildings with tilted roofs had been used will also be considered, increasing the available electricity (still covering partially the electricity demand of the district and heating/cooling the whole dwellings).

The results (see Table 4) show that if only the living rooms of the district are considered, the comfort improvements are much higher (reductions of average excess degree hours of $34 \%$ in winter and $72.6 \%$ in summer). The reason for this is the lower amount of energy necessary to heat/cool the living rooms compared to the whole dwellings, which also decreases the percentage of energy used. An example of the hourly indoor temperatures achieved in the living room of a dwelling compared to its free floating temperature is illustrated in Figure 17, showing the benefits of such a strategy. As for the case that doesn't partially cover the demand of the district, higher reductions are also achieved (from $9 \%$ to $24 \%$ in winter and from $24 \%$ to $44 \%$ in summer). Last of all, if the PV potential of the buildings with tilted roofs had been used, a reduction of almost $33 \%$ could be achieved in winter and $67 \%$ in summer, heating or cooling the whole dwellings.

\begin{tabular}{|c|c|c|c|c|c|c|c|c|c|c|c|}
\hline & \multirow[b]{2}{*}{$\begin{array}{c}\text { Available } \\
\text { exported } \\
\text { electricity } \\
\text { [MWh] }\end{array}$} & \multirow[b]{2}{*}{$\begin{array}{c}\text { Energy } \\
\text { used [\%] }\end{array}$} & \multirow[b]{2}{*}{$\begin{array}{c}\text { Average } \\
\text { number of } \\
\text { activated } \\
\text { dwellings }\end{array}$} & \multicolumn{4}{|c|}{ Winter } & \multicolumn{4}{|c|}{ Summer } \\
\hline & & & & $\begin{array}{c}\text { Excess } \\
\text { degree } \\
\text { hours } \\
{\left[{ }^{\circ} \mathrm{C} \cdot \mathrm{h}\right]} \\
\end{array}$ & $\begin{array}{c}\text { Reduction } \\
{[\%]}\end{array}$ & $\begin{array}{c}\text { Time outside } \\
\text { the confort } \\
\text { zone [\%] }\end{array}$ & $\begin{array}{c}\text { Reduction } \\
{[\%]}\end{array}$ & $\begin{array}{c}\text { Excess } \\
\text { degree } \\
\text { hours } \\
{\left[{ }^{\circ} \mathrm{C} \cdot \mathrm{h}\right]} \\
\end{array}$ & $\begin{array}{c}\text { Reduction } \\
\text { [\%] }\end{array}$ & $\begin{array}{c}\text { Time outside } \\
\text { the confort } \\
\text { zone [\%] }\end{array}$ & $\begin{array}{c}\text { Reduction } \\
{[\%]}\end{array}$ \\
\hline Base Case & - & - & - & 17405 & $0.0 \%$ & $76.3 \%$ & $0.0 \%$ & 11369 & $0.0 \%$ & $72.3 \%$ & $0.0 \%$ \\
\hline $\begin{array}{l}\text { Whole district } \\
\text { (previous case) }\end{array}$ & 178.8 & 96.8 & 45 & 15812 & $9.2 \%$ & $69.9 \%$ & $6.4 \%$ & 8671 & $23.7 \%$ & $62.1 \%$ & $10.2 \%$ \\
\hline Only living rooms & 178.8 & 67.6 & 153 & 11428 & $34.3 \%$ & $55.5 \%$ & $20.8 \%$ & 3117 & $72.6 \%$ & $34.7 \%$ & $37.6 \%$ \\
\hline $\begin{array}{c}\text { All PV generation } \\
\text { is used }\end{array}$ & 392.2 & 94.1 & 62 & 13263 & $23.8 \%$ & $63.1 \%$ & $13.2 \%$ & 6370 & $44.0 \%$ & $51.8 \%$ & $20.5 \%$ \\
\hline $\begin{array}{c}\text { Including } \\
\text { generation of } \\
\text { tilted roofs }\end{array}$ & 698.4 & 80.7 & 123 & 11680 & $32.9 \%$ & $56.9 \%$ & $19.4 \%$ & 3774 & $66.8 \%$ & $38.2 \%$ & $34.1 \%$ \\
\hline
\end{tabular}




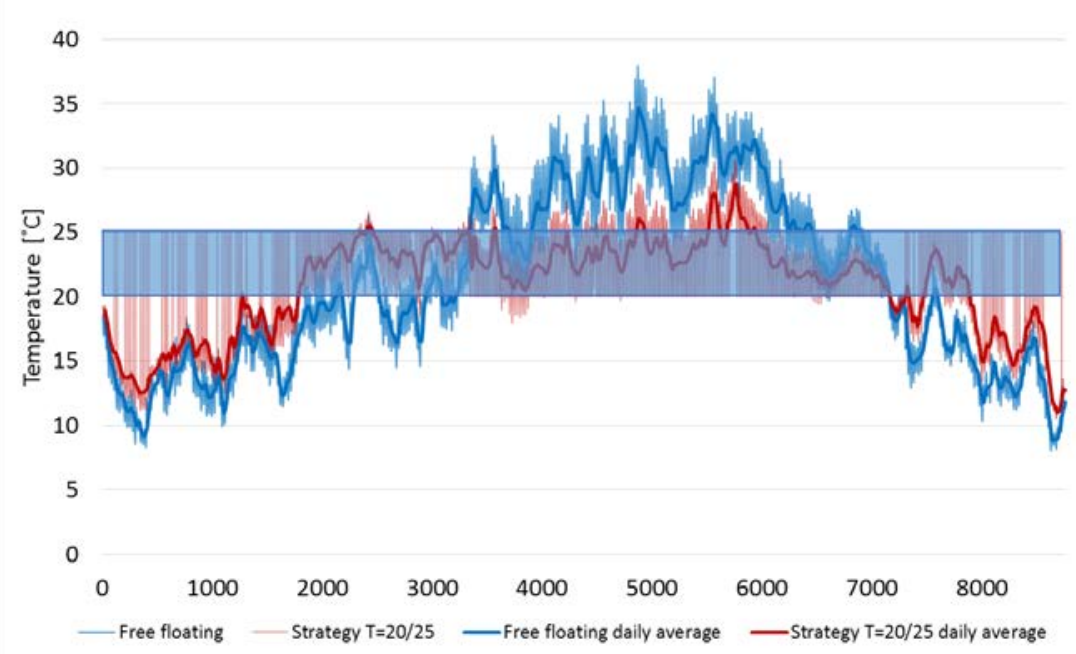

Figure 17: Hourly and daily free floating temperature of the living room in dwelling 147 VS temperatures achieved with strategy $T=20 / 25$.

\section{Conclusions}

In the present work, a novel approach in order to improve the thermal comfort of the occupants in a district at risk of energy poverty has been developed. Taking advantage of the rooftop PV potential in the area, the solar supply is used to cover part of the electricity consumption of the households during the day, reducing their energy bills. Then, instead of using electric storage, the proposal is to use the surplus electricity to supply energy for the heat pumps in the district, heating or cooling the whole dwellings.

First, the optimal strategies from an electrical and economical point of view were chosen, changing the orientation and inclination of the PV modules as well as their separation in order to maximize the solar supply, minimize the investment or maximize the self-sufficiency ratio of the district. The results showed that the solar power supply was maximized by using a southeast orientation, while using a south orientation with less PV modules installed led to the lowest investment, due to the relatively low consumption of the district compared to the PV generation. The self-sufficiency ratio was maximized using a south-west orientation, which favors the solar power supply when the consumption of the district is higher.

After choosing the PV optimal strategies, the surplus electricity in those alternatives was used to share the electricity between the heat pumps of the 235 dwellings of the district. Heating or cooling the whole dwellings, the results showed that the thermal comfort of the occupants could be improved in average up to $11 \%$ in winter and $26 \%$ in summer. If all the PV generation was used, a reduction of $24 \%$ in winter and $44 \%$ in summer could be obtained. On the other hand, if more buildings could be employed to install PV modules, improvements up to $33 \%$ in winter and $67 \%$ in summer could be expected. If only the living rooms of the district were heated, up to $34 \%$ and $73 \%$ reduction in winter and summer respectively could be achieved. In all the cases considered, the thermal comfort differences among the dwellings of the district are reduced significantly, particularly in some of the proposed strategies.

The outcomes of the present work show the potential benefits of the approaches that have been introduced when it comes to tackling energy poverty, even without considering a previous implementation of traditional thermal mitigation strategies. In future work, the synergies between the approaches shown in the present study and traditional retrofitting 
660 strategies will be further analyzed. The reason for this is that the results of thermal comfort 661 improvement shown here will most probably improve if thermal mitigation strategies are 662 previously implemented, due to the reduction of the thermal losses of the buildings which 663 allows to store the energy inside the buildings for longer periods. These proposed alternatives 664 could be used by policy-makers in the future, reducing the energy bills of occupants with 665 monetary restrictions and at the same time improving substantially their thermal comfort.

\section{Acknowledgments}

667 The authors would like to take this opportunity to thank the University of Seville for its 668 financial support through the US Research Plan V (VPPI-US), the Agency for Housing and 669 Rehabilitation in Andalusia (AVRA) for our fruitful long-term cooperation in social housing 670 districts, and the DACAR project "Zero-Energy Balance Districts Through Algorithms of 671 Adaptive Comfort and Optimal Management of Energy Networks" funded by Ministry of 672 Economy and Competitiveness (Government of Spain) for its partial support. 
[1] Bahaj AS, James PAB. Urban energy generation: The added value of photovoltaics in social housing. Renew Sustain Energy Rev 2007;11:2121-36.

doi:10.1016/J.RSER.2006.03.007.

[2] Klein K, Herkel S, Henning H-M, Felsmann C. Load shifting using the heating and cooling system of an office building: Quantitative potential evaluation for different flexibility and storage options. Appl Energy 2017;203:917-37. doi:10.1016/J.APENERGY.2017.06.073.

[3] Le Dréau J, Heiselberg P. Energy flexibility of residential buildings using short term heat storage in the thermal mass. Energy 2016;111:991-1002.

doi:10.1016/j.energy.2016.05.076.

[4] Santamouris M. Innovating to zero the building sector in Europe: Minimising the energy consumption, eradication of the energy poverty and mitigating the local climate change. Sol Energy 2016;128:61-94. doi:10.1016/J.SOLENER.2016.01.021.

[5] Aduda KO, Labeodan T, Zeiler W, Boxem G, Zhao Y. Demand side flexibility: Potentials and building performance implications. Sustain Cities Soc 2016;22:146-63. doi:10.1016/J.SCS.2016.02.011.

[6] Shen L, Li Z, Sun Y. Performance evaluation of conventional demand response at building-group-level under different electricity pricings. Energy Build 2016;128:143-54. doi:10.1016/j.enbuild.2016.06.082.

[7] Lopes RA, Martins J, Aelenei D, Lima CP. A cooperative net zero energy community to improve load matching. Renew Energy 2016;93:1-13.

doi:10.1016/J.RENENE.2016.02.044.

[8] Elsharkawy H, Rutherford P. Retrofitting social housing in the UK: Home energy use and performance in a pre-Community Energy Saving Programme (CESP). Energy Build 2015;88:25-33. doi:10.1016/j.enbuild.2014.11.045.

[9] Gianfrate V, Piccardo C, Longo D, Giachetta A. Rethinking social housing: Behavioural patterns and technological innovations. Sustain Cities Soc 2017;33:102-12. doi:10.1016/j.scs.2017.05.015.

[10] Terés-Zubiaga J, Martín K, Erkoreka A, Sala JM. Field assessment of thermal behaviour of social housing apartments in Bilbao, Northern Spain. Energy Build 2013;67:118-35. doi:10.1016/j.enbuild.2013.07.061.

[11] Santangelo A, Tondelli S. Occupant behaviour and building renovation of the social housing stock: Current and future challenges. Energy Build 2017;145:276-83. doi:10.1016/J.ENBUILD.2017.04.019.

[12] Tirado Herrero S, Jiménez Meneses L, López Fernández JL, Perero Van Hove E, Irigoyen Hidalgo VM, Savary P. Pobreza, vulnerabilidad y desigualdad energética. Nuevos enfoques de análisis. 2016.

[13] Ordóñez J, Jadraque E, Alegre J, Martínez G. Analysis of the photovoltaic solar energy capacity of residential rooftops in Andalusia (Spain). Renew Sustain Energy Rev 2010;14:2122-30. doi:10.1016/j.rser.2010.01.001.

[14] Santamouris M, Alevizos SM, Aslanoglou L, Mantzios D, Milonas P, Sarelli I, et al. Freezing the poor-Indoor environmental quality in low and very low income 
households during the winter period in Athens. Energy Build 2014;70:61-70. doi:10.1016/j.enbuild.2013.11.074.

[15] Romero-Jordán D, Peñasco C, del Río P. Analysing the determinants of household electricity demand in Spain. An econometric study. Int J Electr Power Energy Syst 2014;63:950-61. doi:10.1016/j.ijepes.2014.06.005.

[16] Kolokotsa D, Santamouris M. Review of the indoor environmental quality and energy consumption studies for low income households in Europe. Sci Total Environ 2015;536:316-30. doi:10.1016/j.scitotenv.2015.07.073.

[17] Podgornik A, Sucic B, Blazic B. Effects of customized consumption feedback on energy efficient behaviour in low-income households. J Clean Prod 2016;130:25-34.

[18] Pinto JTM, Amaral KJ, Janissek PR. Deployment of photovoltaics in Brazil: Scenarios, perspectives and policies for low-income housing. Sol Energy 2016;133:73-84. doi:10.1016/J.SOLENER.2016.03.048.

[19] Barbour E, Parra D, Awwad Z, González MC. Community energy storage: A smart choice for the smart grid? Appl Energy 2018;212:489-97. doi:10.1016/J.APENERGY.2017.12.056.

[20] Comello S, Reichelstein S. Cost competitiveness of residential solar PV: The impact of net metering restrictions. Renew Sustain Energy Rev 2017;75:46-57. doi:10.1016/J.RSER.2016.10.050.

[21] Camilo FM, Castro R, Almeida ME, Pires VF. Economic assessment of residential PV systems with self-consumption and storage in Portugal. Sol Energy 2017;150:353-62. doi:10.1016/J.SOLENER.2017.04.062.

[22] Freitas S, Reinhart C, Brito MC. Minimizing storage needs for large scale photovoltaics in the urban environment. Sol Energy 2018;159:375-89. doi:10.1016/J.SOLENER.2017.11.011.

[23] van der Stelt S, AlSkaif T, van Sark W. Techno-economic analysis of household and community energy storage for residential prosumers with smart appliances. Appl Energy 2018;209:266-76. doi:10.1016/J.APENERGY.2017.10.096.

[24] Parra D, Swierczynski M, Stroe DI, Norman SA, Abdon A, Worlitschek J, et al. An interdisciplinary review of energy storage for communities: Challenges and perspectives. Renew Sustain Energy Rev 2017;79:730-49. doi:10.1016/J.RSER.2017.05.003.

[25] Sardi J, Mithulananthan N, Hung DQ. Strategic allocation of community energy storage in a residential system with rooftop PV units. Appl Energy 2017;206:159-71. doi:10.1016/J.APENERGY.2017.08.186.

[26] Nault E, Peronato G, Rey E, Andersen M. Review and critical analysis of early-design phase evaluation metrics for the solar potential of neighborhood designs. Build Environ 2015;92:679-91. doi:10.1016/J.BUILDENV.2015.05.012.

[27] Assouline D, Mohajeri N, Scartezzini J-L. Quantifying rooftop photovoltaic solar energy potential: A machine learning approach. Sol Energy 2017;141:278-96. doi:10.1016/j.solener.2016.11.045.

[28] Parra D, Gillott M, Norman SA, Walker GS. Optimum community energy storage system for PV energy time-shift. Appl Energy 2015;137:576-87. 
doi:10.1016/j.apenergy.2014.08.060.

[29] Brito MC, Freitas S, Guimaraes S, Catita C, Redweik P. The importance of facades for the solar PV potential of a Mediterranean city using LiDAR data. Renew Energy 2017;111:85-94. doi:10.1016/j.renene.2017.03.085.

[30] Mainzer K, Killinger S, McKenna R, Fichtner W. Assessment of rooftop photovoltaic potentials at the urban level using publicly available geodata and image recognition techniques. Sol Energy 2017;155:561-73. doi:10.1016/J.SOLENER.2017.06.065.

[31] Romero Rodriguez L, Duminil E, Sanchez Ramos J, Eicker U. Assessment of the photovoltaic potential at urban level based on 3D city models: A case study and new methodological approach. Sol Energy 2017;146:264-75.

doi:10.1016/j.solener.2017.02.043.

[32] Eicker U, Zirak M, Bartke N, Rodríguez LR, Coors V. New 3D model based urban energy simulation for climate protection concepts. Energy Build 2018. doi:10.1016/j.enbuild.2017.12.019.

[33] Romero Rodríguez L, Nouvel R, Duminil E, Eicker U. Setting intelligent city tiling strategies for urban shading simulations. Sol Energy 2017;157:880-94. doi:10.1016/j.solener.2017.09.017.

[34] Molin A, Schneider S, Rohdin P, Moshfegh B. Assessing a regional building applied PV potential - Spatial and dynamic analysis of supply and load matching. Renew Energy 2016;91:261-74. doi:10.1016/J.RENENE.2016.01.084.

[35] Litjens GBMA, Worrell E, van Sark WGJHM. Influence of demand patterns on the optimal orientation of photovoltaic systems. Sol Energy 2017;155:1002-14. doi:10.1016/j.solener.2017.07.006.

[36] Vieira FM, Moura PS, de Almeida AT. Energy storage system for self-consumption of photovoltaic energy in residential zero energy buildings. Renew Energy 2017;103:30820. doi:10.1016/J.RENENE.2016.11.048.

[37] Jovanovic J, Sun X, Stevovic S, Chen J. Energy-efficiency gain by combination of PV modules and Trombe wall in the low-energy building design. Energy Build 2017;152:568-76. doi:10.1016/j.enbuild.2017.07.073.

[38] Perez KX, Baldea M, Edgar TF. Integrated HVAC management and optimal scheduling of smart appliances for community peak load reduction. Energy Build 2016;123:34-40. doi:10.1016/j.enbuild.2016.04.003.

[39] Widén J. Improved photovoltaic self-consumption with appliance scheduling in 200 single-family buildings. Appl Energy 2014;126:199-212. doi:10.1016/j.apenergy.2014.04.008.

[40] Baldi S, Karagevrekis A, Michailidis IT, Kosmatopoulos EB. Joint energy demand and thermal comfort optimization in photovoltaic-equipped interconnected microgrids. Energy Convers Manag 2015;101:352-63. doi:10.1016/J.ENCONMAN.2015.05.049.

[41] Korkas CD, Baldi S, Michailidis I, Kosmatopoulos EB. Occupancy-based demand response and thermal comfort optimization in microgrids with renewable energy sources and energy storage. Appl Energy 2016;163:93-104. doi:10.1016/J.APENERGY.2015.10.140.

[42] Hurtado LA, Rhodes JD, Nguyen PH, Kamphuis IG, Webber ME. Quantifying demand 
flexibility based on structural thermal storage and comfort management of nonresidential buildings: A comparison between hot and cold climate zones. Appl Energy 2017;195:1047-54. doi:10.1016/j.apenergy.2017.03.004.

[43] Folsom Labs. Helioscope 2018. https://www.helioscope.com/.

[44] Ministry of Development, Unified LIDER-CALENER software Tool (HULC) 2013.

[45] Judkoff R, Neymark J. International Energy Agency building energy simulation test (BESTEST) and diagnostic method. Natl Renew Energy Lab 1995:Size: 296 pages. doi:10.2172/90674.

[46] Monzón M, López-Mesa B. Buildings performance indicators to prioritise multi-family housing renovations. Sustain Cities Soc 2018;38:109-22. doi:10.1016/J.SCS.2017.12.024.

[47] Marta M, Belinda L-M. Simplified model to determine the energy demand of existing buildings. Case study of social housing in Zaragoza, Spain. Energy Build 2017;149:48393. doi:10.1016/J.ENBUILD.2017.04.039.

[48] Rosselló-Batle B, Ribas C, Moià-Pol A, Martínez-Moll V. An assessment of the relationship between embodied and thermal energy demands in dwellings in a Mediterranean climate. Energy Build 2015;109:230-44. doi:10.1016/J.ENBUILD.2015.10.007.

[49] Pérez Gálvez F, Rubio de Hita P, Ordóñez Martín M, Morales Conde MJ, Rodríguez Liñán C. Sustainable restoration of traditional building systems in the historical centre of Sevilla (Spain). Energy Build 2013;62:648-59. doi:10.1016/J.ENBUILD.2012.05.009.

[50] Herrando M, Cambra D, Navarro M, de la Cruz L, Millán G, Zabalza I. Energy Performance Certification of Faculty Buildings in Spain: The gap between estimated and real energy consumption. Energy Convers Manag 2016;125:141-53. doi:10.1016/J.ENCONMAN.2016.04.037.

[51] Aparicio Ruiz P, Sánchez de la Flor FJ, Molina Felix JL, Salmerón Lissén J, Guadix Martín J. Applying the HVAC systems in an integrated optimization method for residential building's design. A case study in Spain. Energy Build 2016;119:74-84. doi:10.1016/J.ENBUILD.2016.03.023.

[52] Aparicio Ruiz P, Guadix Martín J, Salmerón Lissén JM, Sánchez de la Flor FJ. An integrated optimisation method for residential building design: A case study in Spain. Energy Build 2014;80:158-68. doi:10.1016/J.ENBUILD.2014.05.020.

[53] Castellano J, Castellano D, Ribera A, Ciurana J. Developing a simplified methodology to calculate $\mathrm{Co} 2 / \mathrm{m} 2$ emissions per year in the use phase of newly-built, single-family houses. Energy Build 2015;109:90-107. doi:10.1016/J.ENBUILD.2015.09.038.

[54] Hafez AZ, Soliman A, El-Metwally KA, Ismail IM. Tilt and azimuth angles in solar energy applications - A review. Renew Sustain Energy Rev 2017;77:147-68. doi:10.1016/J.RSER.2017.03.131.

[55] Mehleri ED, Zervas PL, Sarimveis H, Palyvos JA, Markatos NC. Determination of the optimal tilt angle and orientation for solar photovoltaic arrays. Renew Energy 2010;35:2468-75. doi:10.1016/J.RENENE.2010.03.006.

[56] Gharakhani Siraki A, Pillay P. Study of optimum tilt angles for solar panels in different latitudes for urban applications. Sol Energy 2012;86:1920-8. 
doi:10.1016/J.SOLENER.2012.02.030.

[57] Bakirci K. General models for optimum tilt angles of solar panels: Turkey case study. Renew Sustain Energy Rev 2012;16:6149-59. doi:10.1016/J.RSER.2012.07.009. 